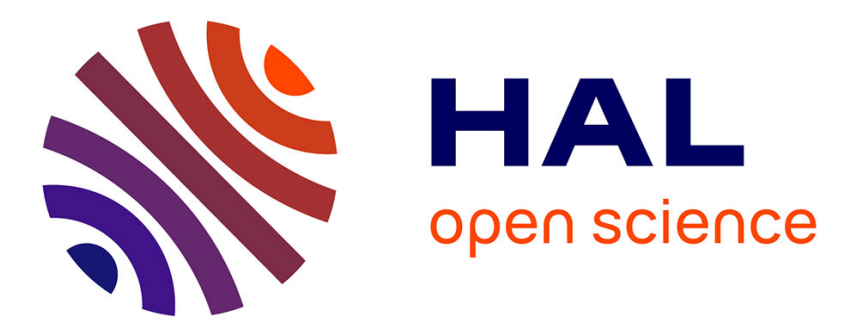

\title{
Assessment of leaching risk of trace metals, PAHs and PCBs from a brownfield located in a flooding zone
}

Martin Seidl, Julien Le Roux, Rémi Mazerolles, Noureddine Bousserrhine

\section{To cite this version:}

Martin Seidl, Julien Le Roux, Rémi Mazerolles, Noureddine Bousserrhine. Assessment of leaching risk of trace metals, PAHs and PCBs from a brownfield located in a flooding zone. Environmental Science and Pollution Research, inPress, 10.1007/s11356-021-15491-0 . hal-03321258

\section{HAL Id: hal-03321258 \\ https://hal-enpc.archives-ouvertes.fr/hal-03321258}

Submitted on 17 Aug 2021

HAL is a multi-disciplinary open access archive for the deposit and dissemination of scientific research documents, whether they are published or not. The documents may come from teaching and research institutions in France or abroad, or from public or private research centers.
L'archive ouverte pluridisciplinaire HAL, est destinée au dépôt et à la diffusion de documents scientifiques de niveau recherche, publiés ou non, émanant des établissements d'enseignement et de recherche français ou étrangers, des laboratoires publics ou privés. 
1 Assessment of leaching risk of trace metals, PAHs and PCBs 2 from a brownfield located in a flooding zone

3

\author{
Martin SEIDL ${ }^{1 *}$, Julien LE ROUX ${ }^{2}$, Rémi MAZEROLLES ${ }^{1}$, Noureddine \\ BOUSSERRHINE ${ }^{2}$ \\ ${ }^{1}$ LEESU ENPC, Université Paris-Est, 6-8 avenue Blaise Pascal, 77455, cedex 2 Marne la Vallée, France \\ ${ }^{2}$ LEESU UPEC, Université Paris-Est Créteil, 61 avenue du Général de Gaulle, 94010 Créteil Cedex, France \\ * Corresponding author: martin.seidl@enpc.fr
}

\begin{abstract}
An old industrial site (brownfield) located south of Paris in a flooding plain and containing demolition disposal as well as a burning zone for metal recovery is being regenerated to satisfy local need for public green space. The main objective of the described study was therefore to assess the risk of remobilisation of trace metals, PAH and PCB present. The research focused on vertical migration due to rainfall (non-saturated flow) and to river flooding (saturated flow). To assess the remobilisation risk, representative soil profiles were reconstituted and eluted in columns with artificial rain and filtered river water for six weeks with an equivalent of $25 \mathrm{~mm} \mathrm{~d}^{-1}$. Soil analysis showed that both zones are highly contaminated, exceeding the French environmental standards. Though the superficial metal content was much higher in the burning zone with levels of $\mathrm{g} \mathrm{kg}^{-1}$ than in the demolition zone, most metals showed higher levels in the eluents of the latter. The level of dissolved $\mathrm{Zn}$ in the burningzone eluent was $30 \mu \mathrm{g} \mathrm{L}^{-1}$ while in the demolition-zone it was $300 \mu \mathrm{g} \mathrm{L}^{-1}, 40$ times the admissible level. $\mathrm{Zn}$ was thereby correlated to aromaticity parameter HIX, indicating a link with organic matter transformation. The $\mathrm{Cu}$ was only significantly released under saturated condition (up to $80 \mu \mathrm{gL}^{-1}$ ) in the demolition soil, indicating as implicated mechanism manganese and iron oxide reduction rather than organic matter transformation. Despite the high PAH and PCB soil contents, these pollutants were not released. The total PAH content in the effluent was $30 \mathrm{ng} \mathrm{L}^{-1}$ in average and did not significantly differ between the two zones and the types of hydrology. Only $\mathrm{Zn}$ and $\mathrm{Cu}$ issued from demolition zone presented an eco-toxicological risk. Crossed statistical analysis of the results showed that the role of the soil type is preponderant in the pollutant release and that temporary flooding condition would induce a lower impact on the ground water quality than an equivalent amount of fallen rain. Though the burning site was far more contaminated in the upper soil than the demolition zone, it presented little risk compared to the demolition-zone, more profound and more permeable. The latter showed therefore significative trace metal release, up to $2.1 \mathrm{~kg} \mathrm{ha}^{-1}$ year $^{-1}$ for zinc, doubling the local atmospheric deposition.
\end{abstract}

\title{
Keywords
}

Soil contamination; Pollutant remobilisation; Rain; Flood; Heavy metals; Organic micropollutants; Saturated and unsaturated flow conditions; Column experiments; Environmental impact

\section{Introduction}

Generally, brownfield sites exist in a city's or town's industrial sections, on locations with abandoned factories or commercial buildings or other previously polluting activities. Typical contaminants found on contaminated brownfield land include hydrocarbon spillages, solvents and heavy metals. The regeneration of brownfields has gained prominence due to their potential to satisfy urban expansion and to promote green areas. 
In France, the most treated pollutants in brownfield soils are the total hydrocarbons (HC), the organohalogen volatile compounds (OHVC) and heavy metals, representing together nearly $80 \%$ of the brownfield pollutants. The principal pollutants in groundwaters are also OHVC and HC, representing $47 \%$ of the pollutants. The "other pollutants" usually include cyclohexane, pentachlorophenol (PCP), asbestos, cyanides and sulphates (ADEME 2014).

The Pierre-Fitte study site (ENPF 2017) is located in the industrial area of Villeneuve-le-Roi (France), more particularly in the docks of Carelle port on the left bank of the river Seine, $20 \mathrm{~km}$ upstream of Paris. It is representative of typical polluted brownfields, with high levels of heavy metals and several spots of organic micropollutants (Guittard et al. 2013). The long-term annual precipitation of the region is $650 \mathrm{~mm}$, and the mean annual air temperature is $12.1^{\circ} \mathrm{C}$. The area still accommodates various types of companies like trade of construction material, recycling of paper and scrap and petrol deposit (Souvestre 2013). The site may be periodically flooded in the spring by the river Seine depending on rain distribution and dam management upstream (DRIEE 2015). The flood return period is about 25 years, and the last ones registered occurred in 2016 and 2018 (DRIEE 2018). Since the 3-ha brownfield is planned to be regenerated as green space for local inhabitants, local authorities evaluated its sanitary risks in 2013 (Guittard and et al. 2013). The area shows two main zones of contamination: a 50-yearold demolition disposal (called DEM) and a more recent spot where electric equipment was burned for metal recovery (called BURN) (Figure 1). The heavy metal content of the DEM zone is actually too high to allow public access and should be therefore decontaminated in the future by phytoremediation. The $\mathrm{Zn}$ concentration map based on the data obtained from the preliminary risk assessment (Guittard and et al. 2013) is shown in Figure 1.

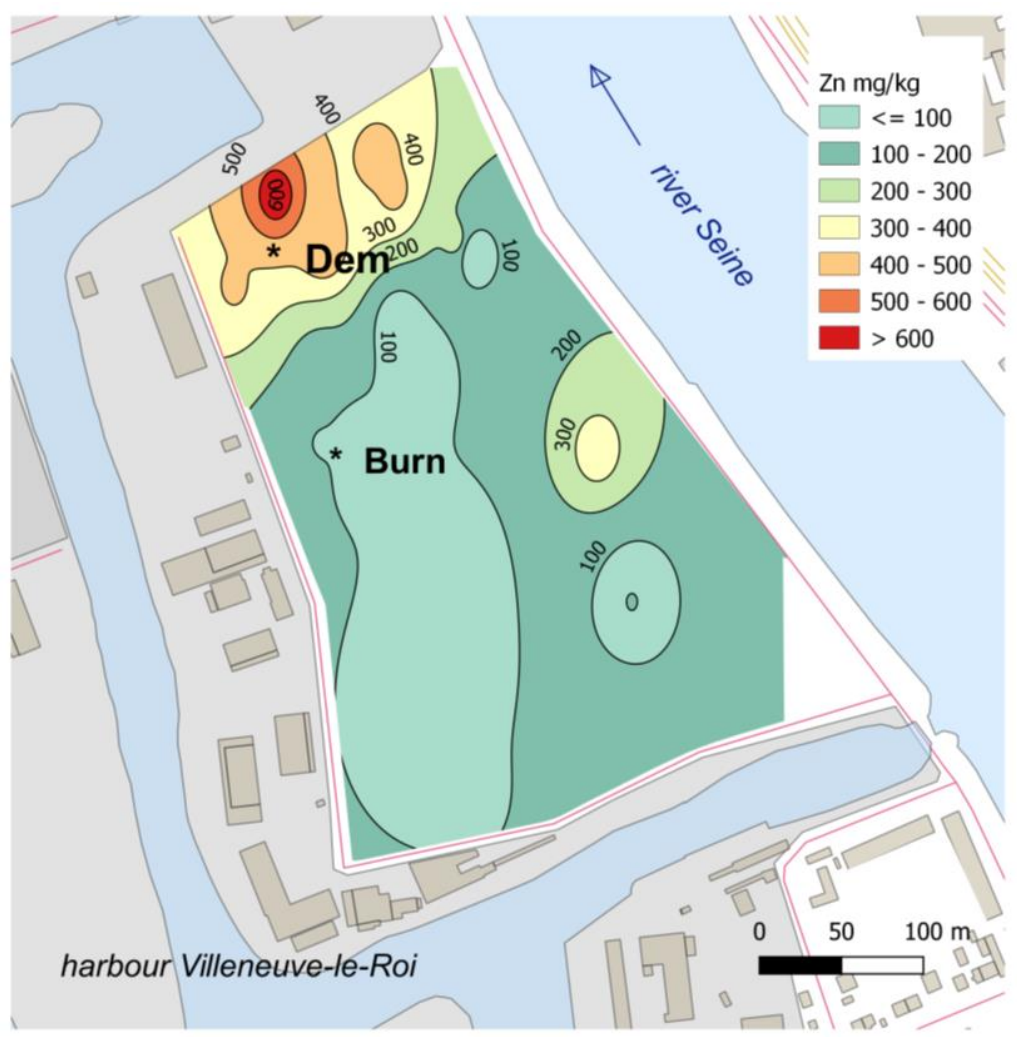

Fig. 1 Position of the brownfield and the sampling sites DEM and BURN, together with the intensity of zinc contamination (ppm), using the data of CD94 County survey (Guittard et al. 2013). The bottom left corner corresponds to GPS coordinates 48.7374427 N, 2.4371572 E. 
Floodplains act as a link between terrestrial and aquatic ecosystems. They underlie large seasonal

fluctuations of the water table that induce varying compositions of the interstitial solution and redox conditions. Moreover, periodical floods result in the deposition of sediments and casually in concomitant inputs of dissolved and particulate contaminants. Varying conditions of redox potential, which are seasonally found in floodplain soils (Shaheen and Rinklebe 2014), may induce the precipitation or reductive bacterial dissolution of $\mathrm{Mn}$ and Fe oxides acting as carrier phases for heavy metals and, under strictly reducing conditions, the formation of sparingly soluble metal sulphides (Bousserrhine et al. 1999; Suna Erses and Onay 2003; Du Laing et al. 2009; Gounou et al. 2010; Harris-Hellal et al. 2011). Even though the river Seine floods upstream of Paris are relatively short events (level rise during 1 or 2 days, level decrease 1 or 2 weeks), such conditions might also be present in the area studied.

On most contaminated sites, monitoring of groundwater and interstitial water is not feasible due to field conditions like lack of physical accessibility, high heterogeneity of underground, administrative limitations and limited financial support. Therefore, laboratory tests have been set up to simulate field conditions and to allow sampling of all components using simplified techniques (Van der Sloot 1996). Numerous procedures exist to simulate the leaching of pollutants from soil (Dermont et al. 2008; US EPA 2015). These tests can be principally divided in batch-leaching tests (i.e. a soil sample is leached with water or a specific solution at a predefined liquid/solid (L/S) ratio and reaction time) and column experiments, where contaminant release from soil is studied under controlled and more realistic flow conditions. Column experiments offer, moreover, the option of modification of experimental conditions like flow velocities and flow interruptions to better identify the kinetics of contaminant release (Rennert et al. 2010). To estimate the metal mobility, numerous studies determined the sequential metal content (Thums et al. 2008; Gounou et al. 2010; Li et al. 2015) or standardised leachability of organic pollutants (Van der Sloot 1996; Reemtsma and Mehrtens 1997; Cappuyns and Swennen 2008; Tian et al. 2015; US EPA 2017; ISO 2019), but only few of them focused on biogeochemical or hydrological process involved in pollutant release and behaviour (Gounou et al.2010; Harris et al. 2011; Fang et al. 2016). Although natural leaching processes occurring in situ can be best reproduced in the laboratory by column experiments with undisturbed soil or sediment profile (Camobreco et al. 1996; Schuwirth and Hofmann 2006), only few recent papers use this approach, principally due to a more complex and work-intensive methodology (Pot et al. 2011; Gonzalez et al. 2019; Cueff et al. 2020). Nevertheless, these authors use simplified, constant and unsaturated flow conditions. Some authors, like Rennert and Rinklebe (2010), used a saturated approach to compensate these shortcomings, though they applied homogenised sieved soils. The originality of our paper is therefore a combination of column experiments with reconstituted natural soil profiles and intermittent, saturated and unsaturated flows to assess the mobilisation risk as close as possible to the hydrological field conditions.

Based on a preliminary environmental assessment (Guittard and et al. 2013) revealing contamination with heavy metals, the main objective of this study was to provide an extensive evaluation of in-depth contamination by trace metals, PAH and PCB and to evaluate their mobility according to various hydrological scenarios present on site. The aim of proposed work was therefore to answer the following specific questions: What is the risk of contamination of groundwater linked to present contamination? Is there any specific risk of remobilisation of pollutants due to flooding? To what degree do the soil structure and biogeochemical conditions contribute to the pollutant mobility? What are the differences between trace metals and organic micropollutants in terms of remobilisation and associated processes? 


\section{Materials and methods}

As the process in situ is more accurately simulated by column experiments (Schuwirth and Hofmann 2006), with undisturbed soil profile (Camobreco et al. 1996), this approach was applied in the present study. Due to the presence of large fragments of construction material or electric cables in the soil, it was not possible to get undisturbed soil columns in situ and reconstitution of representative soil profiles was performed in the laboratory. Since the brownfield is situated in the flooding zone, the evaluation focused on the (vertical) pollutant mobility induced by rainfall (non-saturated percolation) or as consequence of river flooding (saturated percolation). As rain and flooding are recurrent processes intermittent water supply was applied.

\section{Soil sampling}

Soil sampling was carried out on two areas of the Carelle site: the DEM area, a 50-year-old demolition disposal and the BURN area, a more recent spot where electric equipment was burned for metal recovery, in the beginning of April 2016, 1 week after a rainfall. For each sampling area, three points were chosen at equidistance ( $30 \mathrm{~m}$ for DEM and $5 \mathrm{~m}$ for BURN), south, east and west from the pollution spot centre. At each point, surface plants and objects larger than $10 \mathrm{~cm}$ were removed and the soil was excavated on a square of 50 by $50 \mathrm{~cm}$, per layer of $10 \mathrm{~cm}$ to a depth of $50 \mathrm{~cm}$, sufficient to sample the whole organic soil horizon, the most microbiologically active layer. The soil of each layer was homogenised and quartered, where after the half of one portion was taken as a representative sample of the layer. In the laboratory, the soil samples were sieved at field humidity subsequently with $1-\mathrm{cm}$ and $2-\mathrm{mm}$ mesh. The fraction of $2 \mathrm{~mm}$ was kept refrigerated at $6^{\circ} \mathrm{C}$ until the column experiments and soil analysis.

\section{Column operation}

For the two sampling areas (DEM and BURN), the layers coming from the same depth of three sampling points were mixed to obtain composite layers, representative for the entire area (i.e. 5 composite layers for each sampling area). These composite samples were used for extended soil analysis and to pack the columns.

The columns were constituted from standard PVC water pipes and closures, with a large internal diameter of $153 \mathrm{~mm}$ to avoid border effects. A drainage layer of $3 \mathrm{~cm}$ of gravel (mainly quartz) was placed at the bottom of the column, surmounted by a PE geotextile membrane (Onduline). Gravel and sand were soaked overnight in $2 \%$ nitric acid to remove any trace of limestone and metals and were washed prior to use. All columns were cleaned with detergent (Extran), 2\% HNO3 and distilled water before experimentation. The cleaned empty columns, together with gravel, sand and geotextile were entirely filled with the same eluent used for the experiments (see below) and left for $24 \mathrm{~h}$ in the dark at room temperature to determine the background pollution (blank samples). Afterwards, the columns were packed with subsequent composite layers according to their field depth and mass, based on the field wet density to constitute a representative soil profile with approximate field hydraulic conductivity. The separation between layers were marked by a small stripe of geotextile to make their final analysis possible. The top of the column was covered again by geotextile and a 2-cm layer of quartz sand to guarantee a homogenous water distribution (Figure 2).

For each study area, DEM and BURN, two columns were prepared, one to simulate rainfall (unsaturated percolation) and the other to simulate exposition during flooding (saturated elution). Artificial rainwater was produced according to the rain composition in Paris region (Kafi et al. 2008; Seidl et al. 2013) by diluting twice the commercial mineral water Mont Roucous with MilliQ water, stocked in the dark prior to use. River water came from the entrance of the harbour Villeneuve-le-Roi 
and was filtered on oven cleaned $\left(2 \mathrm{~h} 550^{\circ} \mathrm{C}\right)$ glass microfibre filter (Whatman GF/F, approx. porosity $0.7 \mu \mathrm{m})$ and stocked in the dark prior to use.

1 Site $\rightarrow 3$ points, sampled per layer $\quad \rightarrow \quad 2$ Columns in lab

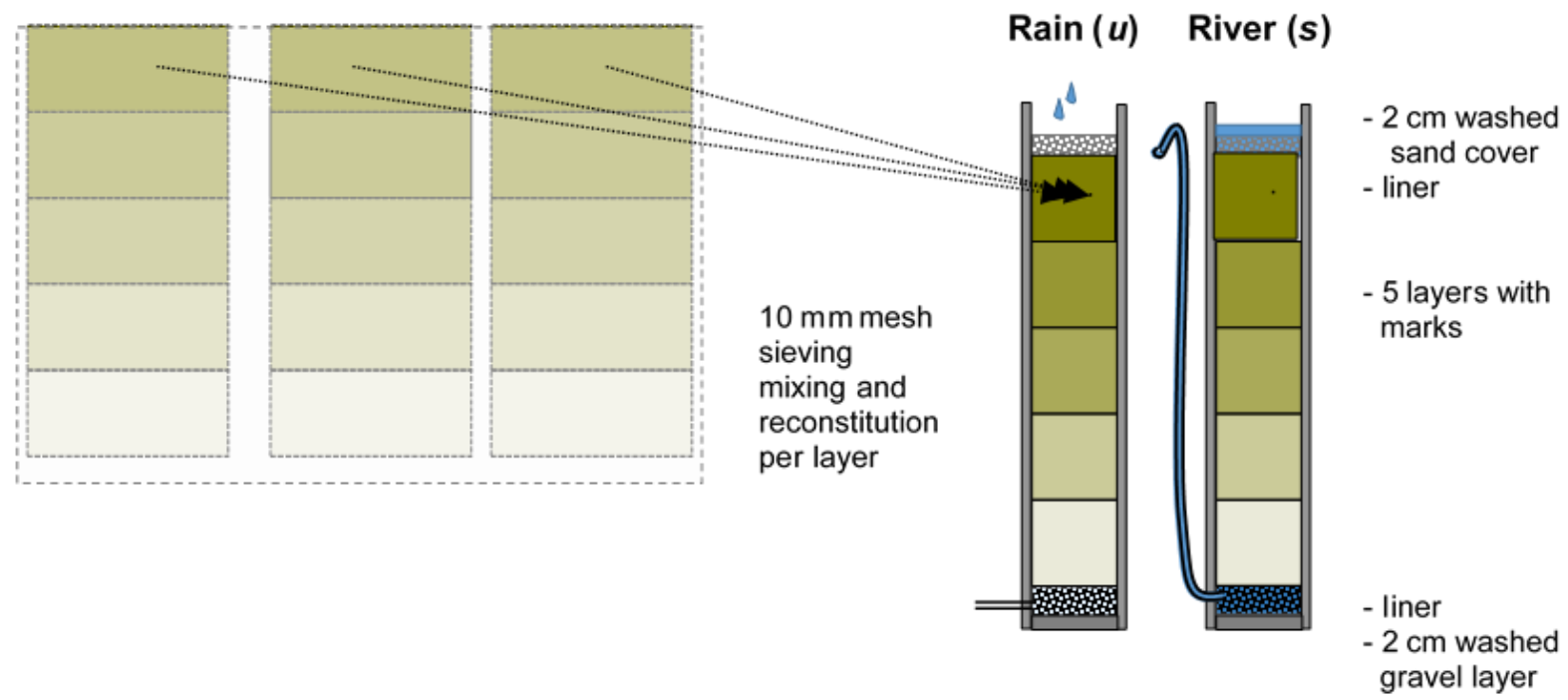

Fig. 2 Set-up and operation of unsaturated (u-DEM and u-BURN) and saturated columns (s-DEM and s-BURN)

Rainfall was simulated by sprinkling $2.3 \mathrm{~L}$ of artificial rainwater through 5 irrigation gutters at the top of the column twice a week (Monday and Thursday afternoon) at approximate flow of $1 \mathrm{~L} \mathrm{~h}^{-1}$, equivalent to a "rainfall" of $125 \mathrm{~mm}$ (u-DEM and u-BURN) columns. Columns s-DEM and s-BURN, simulating the flood conditions (fast rise of groundwater level in the beginning of the flood, followed by slow infiltration of remaining flood water) were initially saturated by river water by the bottom of the column, where after $2.3 \mathrm{~L}$ of river water was applied at the top of the column, the columns were kept saturated by a siphenoid outflow. The resulting hydraulic regime corresponded to 4-6 h of percolation followed by 3 days of retention. The apparent vertical Darcy velocity, determined from flow and cross section, varied according to the soil type from 2 to $8 \times 10^{-5} \mathrm{~m} \mathrm{~s}^{-1}$, similar to those found in situ (Table 1) and to those used by others, in comparable set-up (Rennert et al. 2010). Whole samples were collected at the bottom of the column at the end of percolation the morning after the application. The total water height applied on each column was $1500 \mathrm{~mm}$ for 6 weeks of experiment.

\section{Analytical methods}

All analyses were performed following the US (APHA et al. 2012) and French (AFNOR 2002, 2005) analytical and GLP recommendations. For metal analysis, certified reference materials were used for result verification.

Estimation of granulometry was obtained on AFNOR-certified stainless-steel sieves at $10 \mathrm{~mm}$ and at $2 \mathrm{~mm}$. All specific soil analyses were done on the crushed $2-\mathrm{mm}$ fraction dried at $40^{\circ} \mathrm{C}$ for 7 days to limit the organic pollutant evaporation/degradation. The soil humidity and porosity were estimated as water loss at $105^{\circ} \mathrm{C}$ on unsaturated and saturated standard ring samples $(100 \mathrm{ml})$ taken in each column layer at the end of experiments. The soil organic matter was estimated as dry volatile matter after ignition loss at $550^{\circ} \mathrm{C}$ for $8 \mathrm{~h}$. The total organic and inorganic soil carbon content were determined on COT metre (OI Analytical), and the total soil heavy metal content was screened by fluorescence $\mathrm{X}$ (portable XRF analyser Bruker). The hydraulic conductivity was measured in the field by the Guelph permeameter (Nasri et al. 2015) and determined in the laboratory as flow rate during the first hour of the percolation. 
The leachate conductivity and $\mathrm{pH}$ were measured using a TetraCon 325 sensor and Sentix 41-3 KClelectrode (WTW Multi-parameter 340i). Turbidity was determined with a portable turbidimeter (Hach 2100P).

Liquid samples for metal analysis were vacuum filtered using disposable PE tubes including $0.45-\mu \mathrm{m}$ PTFE filters (Digiprep SA, France) and acidified by adding $1 \%$ of concentrated $\mathrm{HNO}_{3}$ (Merck ultrapure). Liquid samples for DOC and organic micropollutants analysis were vacuum filtrated on oven treated $\left(2 \mathrm{~h}\right.$ at $\left.550^{\circ} \mathrm{C}\right)$ using glass support and microfibre filter (Whatman GF/F). Any vessel used for the metal analysis was soaked overnight in $2 \%$ Extran detergent (Merck) aqueous solution, followed by $24 \mathrm{~h}$ in $2 \% \mathrm{HNO}_{3}$ solution and rinsed with tap, distilled and ultra-pure water $(18 \mathrm{M} \Omega$, MilliQ Millipore). Any vessel used for the organic micropollutant and DOC analysis was soaked overnight in 2\% TFD4 detergent (Franklab SA, France) aqueous solution and rinsed abundantly with tap and distilled water and air-dried and, if necessary, oven cleaned at $550^{\circ} \mathrm{C}$ for $2 \mathrm{~h}$.

Dissolved organic carbon (DOC) was measured using an IR spectrometer (OI Analytical) on filtered samples preserved with $1 \%$ orthophosphoric acid (VWR, $85 \%$ ). UV absorbance was obtained on filtered samples on a UV spectrometer (Secoman UV-Line 9400, France) and three-dimensional fluorescence excitation-emission matrices (EEMs) were obtained on a fluorescence spectrometer (Jasco FP-8300, Japan). Specific UV absorbance at $254 \mathrm{~nm}$ (SUVA) was calculated as the ratio between UV absorbance at $254 \mathrm{~nm}$ and DOC concentration. Specific fluorescence indexes for dissolved organic matter, BIX and HIX, were determined according to Huguet (Huguet et al. 2010) and Zsolnay (Zsolnay et al. 1999).

Trace metals were analysed in acidified $\left(2 \% \mathrm{HNO}_{3}\right.$ ultrapure, Merck) eluents and in mineralised soil samples by ICP-AES (Spectroblue, Ametek, USA). The mineralisation of soil samples was performed in DigiPREP MS system (SCP Science) at $95^{\circ} \mathrm{C}$ using three successive steps: 30 min with nitric acid (Suprapur 65\%, Merck) followed by 30 min with hydrogen peroxide (30\% AnalaR Normapur, VWR) and finalised by $15 \mathrm{~min}$ with hydrochloric acid (37\%, Fisher Scientific, Analytical grade).

PAHs and PCBs in dissolved phase were extracted by solid phase extraction (SPE) on Chromabond C18 6-mL 2000-mg cartridge (Macherey-Nagel) with an AutoTrace SPE Work Station (Caliper Life Sciences, USA). PAHs and PCBs in the particulate phase were extracted by Multiwave 3000 microwave (Anton Paar, Austria). Both types of samples were quantified using a gas chromatograph (Thermo Focus GC) coupled with a mass spectrometer (Trace DSQ, Thermo Electron Corporation, USA) in single ion monitoring (SIM) mode. A standard mixed containing 16 PAHs (SV Calibration Mix \#5/610) was supplied from Restek. An internal standard mix (PAH-Mix 31) containing 5 deuterated PAHs, an additional internal standard (pyrene-d10), a mixed standard containing 15 PCB congeners, and 3 additional PCBs used as internal standards were purchased from LGC Promochem. Analytical details for PAHs and PCBs can be found elsewhere (Bressy et al. 2011).

Enrichment factors were calculated as a ratio of trace metal mass to iron mass or as organic micropollutant compound mass to organic carbon mass, compared to equivalent ratio of a reference material according to Bern et al. (Bern et al. 2019).

Statistical analysis of data was conducted using the R environment (RFSC 2019) and XLSTAT (Adinsoft 2018). 


\section{Results and discussions}

\section{Soil contamination}

Based on the particle size distributions, using the diagram of Pourbey, the DEM samples can be classified, in the range of silty sand soils and the BURN samples in the silty loam soils. While the DEM soil showed increasing silt content with depth, no significant modification of vertical distribution could be observed for the BURN soil. The dry bulk density increased with depth for both types of soil, varying from $1.2 \mathrm{~g} \mathrm{~cm}^{-3}$ at the surface to $1.5 \mathrm{~g} \mathrm{~cm}^{-3}$ at $50-\mathrm{cm}$ depth. Due to the presence of incompletely buried waste in the second sublayer of the BURN soil, its profile showed a peak of porosity and particulate carbon at $15-\mathrm{cm}$ depth (Figure 3). The difference between the two soil types was even greater by considering the (high) proportion of coarse particles $(>2 \mathrm{~mm}$ ) in the DEM soil (Table 1). The loam and silt-loam classes (Clapp and Hornberger 1978) have typically a permeability of $10^{-6} \mathrm{~m} \mathrm{~s}^{-1}$, ranging between $10^{-7} \mathrm{~m} \mathrm{~s}^{-1}$ for pure silt to $10^{-5} \mathrm{~m} \mathrm{~s}^{-1}$ for sandy loam (Dunne and Leopold 1978; Dingman 2015). Due to the brick fraction and stone content in the DEM soil as observed in situ, the conductivity measured by the Guelph permeameter in the field was around $5.10^{-5}$ $\mathrm{m} \mathrm{s}^{-1}$, i.e. higher than the superior limit of $10^{-5} \mathrm{~m} \mathrm{~s}^{-1}$ for sandy loams. The average values of general parameters for both types of soils are given in Table 1 .
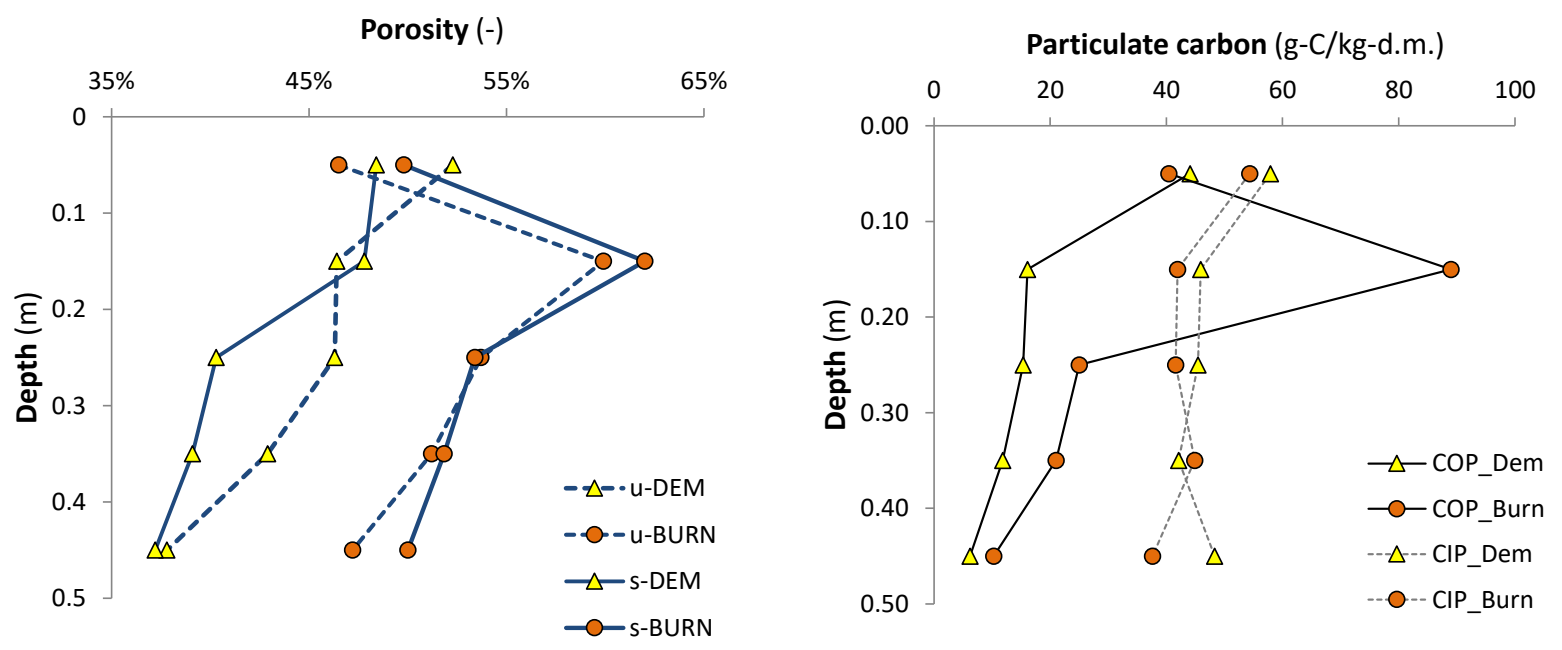

Fig. 3 Reconstituted porosity and particulate carbon profile in the experimental columns 
Table. 1 Soil characteristics $(n=10)$

\begin{tabular}{|c|c|c|c|c|c|c|c|c|c|c|}
\hline \multicolumn{6}{|c|}{ Field } & \multicolumn{5}{|c|}{ Column } \\
\hline & $\begin{array}{c}\mathrm{d}<2 \\
\mathrm{~mm} \\
(\%)\end{array}$ & $\begin{array}{c}2<\mathrm{d}<10 \\
\mathrm{~mm} \\
(\%)\end{array}$ & $\begin{array}{c}\mathrm{d}>10 \\
\mathrm{~mm} \\
(\%)\end{array}$ & $\begin{array}{c}\text { Humidity } \\
(\%)\end{array}$ & $\begin{array}{c}\text { Permeability } \\
\left(\mathrm{m} \mathrm{s}^{-1}\right)\end{array}$ & $\begin{array}{c}\text { Porosity } \\
(\%)\end{array}$ & $\begin{array}{l}\text { dry density } \\
\left(\mathrm{g} \mathrm{cm}^{-3}\right)\end{array}$ & $\begin{array}{l}\text { VS } \\
(\%)\end{array}$ & $\begin{array}{c}\text { POC } \\
(\%)\end{array}$ & $\begin{array}{l}\text { PIC } \\
(\%)\end{array}$ \\
\hline DEM & 55.0 & 24.4 & 20.6 & 13.8 & $5.10^{-5}$ & 43.8 & 2.46 & 5.1 & 1.9 & 4.8 \\
\hline std & 5.0 & 7.0 & 6.8 & 2.0 & & 5.1 & 0.18 & 2.0 & 1.0 & 1.0 \\
\hline BURN & 88.6 & 7.6 & 3.8 & 20.6 & n.d. & 52.6 & 2.80 & 8.6 & 3.7 & 4.4 \\
\hline$s t d$ & 4.0 & 3.0 & 3.0 & 4.0 & & 5.0 & 0.24 & 3.0 & 3.0 & 1.0 \\
\hline
\end{tabular}

VS volatile solids, POC particulate organic carbon, PIC particulate inorganic carbon, std standard deviation

283

284

285

286

287

288

289

290

291

292

293

294

295

296

297

298

299

300

301

The results of X-ray fluorescence analysis (Figure 4) and organic contaminants analysis (Figure 5) confirmed that both zone are highly contaminated and exceeding the French environmental standards (Legifrance 1998; MEDDM et al. 2009). The values found are in the range of that found during the environmental screening in 2013 (Figure 1) (Guittard and et al. 2013). As expected, the BURN zone exhibited high levels of PAH (up to $39.9 \mathrm{mg} \mathrm{kg}^{-1}$ ) and copper (53 to $154 \mathrm{mg} \mathrm{kg}^{-1}$ ). Surprisingly also, high levels of lead and zinc (1623 and $316 \mathrm{~g} \mathrm{~kg}^{-1}$ in average, respectively) were found in this zone, even higher than in the demolition zone (DEM) (Table 2). The high lead concentrations accompanied by antimony indicate a possible activity of retreatment of lead-acid batteries (Jin et al. 2015). Because of waste burning, the BURN zone was principally polluted in the upper $30 \mathrm{~cm}$, and deeper layers contained natural sediments (silt) without any trace of physical anthropogenic perturbation. The DEM zone showed traces of anthropogenic pollution over the whole depth in the form of bricks, plastic and iron parts and presented therefore a minor vertical gradient as compared to the BURN zone. Iron and manganese concentrations did not show any vertical variation (data not shown). Iron concentration was higher in the BURN zone soil than in the DEM zone soil (7.2 and $4.4 \mathrm{~g} \mathrm{~kg}^{-1}$, respectively) DEM and manganese concentrations were similar in both soils (about $0.1 \mathrm{~g} \mathrm{~kg}^{-1}$ ). Compared to natural values of enrichment of 0.025 for $\mathrm{Zn} / \mathrm{Fe}$ and $0.004 \mathrm{for} \mathrm{Cu} / \mathrm{Fe}$ (Baize 2000) the DEM factor is a double, and that of copper in BURN soil is a hundred fold.
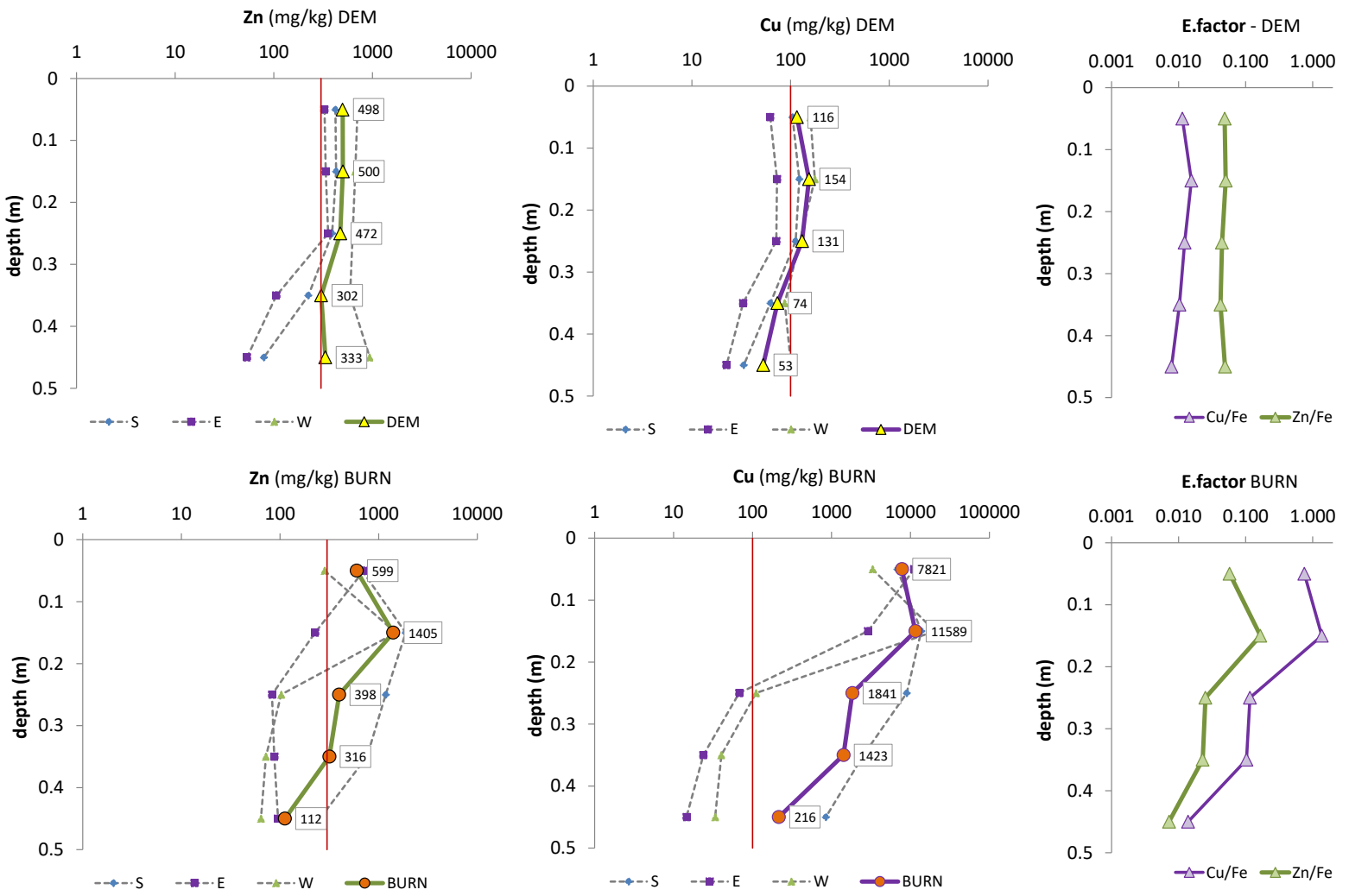
Fig. 4 DEM zone on the top and BURN below. Zinc and Copper profiles of the fraction $<2 \mathrm{~mm}$ as found in the brownfield, showing the spatial heterogeneity of the pollution: south (S), east (E) and west (W) of the pollution spot centre. Solid line represents the column composite used for the column experiments. The vertical red line indicates the French limits for wastewater sludge amendments of agricultural land. For both, trace metal enrichment factors are shown.

As expected, beside trace metals, the brownfield was also contaminated by organic pollutants like PAH and PCB (Figure 5). The burning zone (BURN) was more contaminated especially in the top layers than the zone containing demolition material (DEM). The average contamination observed of around tenth of $\mathrm{m} \mathrm{kg}^{-1}$ of total PAH is below the range of industrial contamination of 100 to 1000 $\mathrm{mg} \mathrm{kg}^{-1}$ often mentioned in the literature (Crone 2001; Wang et al. 2010). However taking median values for arable land of $0.7 \mathrm{mg} \mathrm{kg}_{-\mathrm{Dw}}{ }^{-1}$ (Motelay-Massei et al. 2004; Holoubek et al. 2009) as background value, even the underground of BURN zone should be considered as contaminated, classifying the whole soil profile as urban or as industrial. Normalisation with carbon showed that DEM soil was 10 times more polluted than the BURN soil.
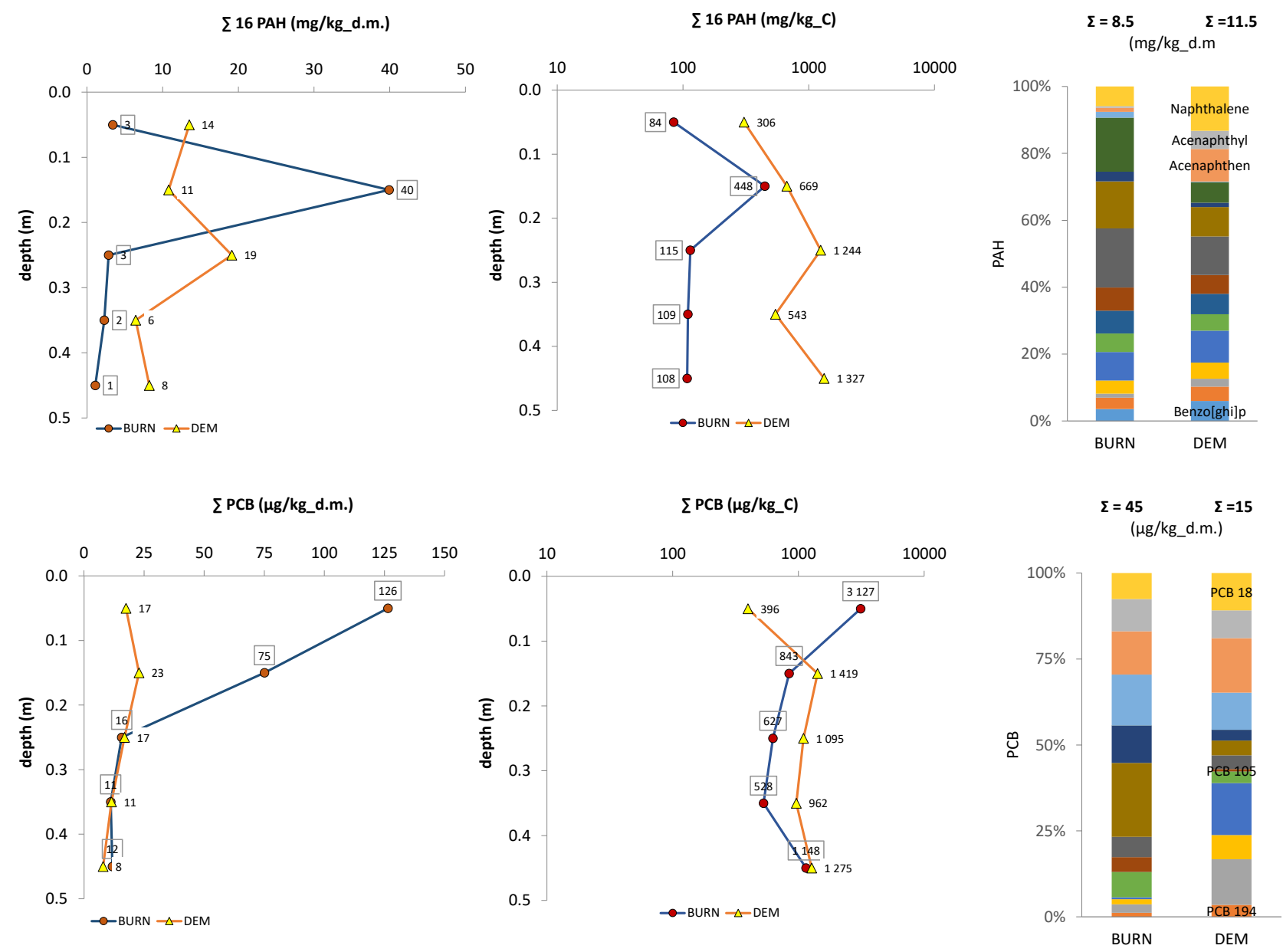

Fig. 5 Vertical profile of $16 \mathrm{PAH}$ and their composition (above) and the equivalent of 18 PCB (below) for the two types of soil as used in the test columns. The bar charts have the components classified from the lowest molecular weight on the top (e.g. naphtalene and PCB 18) to the highest on the bottom (e.g. benzo[ghi]perylene and PCB 209). 
Like PAH, the PCBs were mainly present in the BURN soil, though more at the surface. Compared to levels of $10-20 \mathrm{mg} \mathrm{kg}^{-1}$ found in rural areas in the Seine river basin (Motelay-Massei et al. 2004) the PCB levels of the upper soil of the BURN zone (up to $126 \mathrm{mg} \mathrm{kg}^{-1}$ ) can be characterised as industrial pollution. The PCB distribution indicates a possible contamination with Aroclors as could be present in electric and electronic equipment (ATSDR and USDHHS 2000).

The different PCB and PAH distributions between the two zones, especially if normalised by organic soil carbon concentrations, demonstrate that the type of contamination is different from one zone to another and is characteristic of the activity in each zone.

Table. 2 The micropollutant concentrations of soils used in the column experiments

\begin{tabular}{lccc}
\hline Zone & $\begin{array}{c}\text { Unit } \\
\text { Species }\end{array}$ & $\begin{array}{c}\text { DEM } \\
\text { Average }\end{array}$ & $\begin{array}{c}\text { BURN } \\
\text { Average }\end{array}$ \\
\hline $\mathrm{Al}$ & $\mathrm{mg} \mathrm{kg}^{-1}$ & 2389 & 8734 \\
$\mathrm{Cd}$ & $\mathrm{mg} \mathrm{kg}^{-1}$ & 1.512 & 1.630 \\
$\mathrm{Co}$ & $\mathrm{mg} \mathrm{kg}^{-1}$ & 0.898 & 1.377 \\
$\mathrm{Cr}$ & $\mathrm{mg} \mathrm{kg}^{-1}$ & 9.760 & 17.77 \\
$\mathrm{Cu}$ & $\mathrm{mg} \mathrm{kg}^{-1}$ & 31.88 & 1798 \\
$\mathrm{Fe}$ & $\mathrm{mg} \mathrm{kg}^{-1}$ & 4420 & 7181 \\
$\mathrm{Mn}$ & $\mathrm{mg} \mathrm{kg}^{-1}$ & 103 & 159 \\
$\mathrm{Mo}$ & $\mathrm{mg} \mathrm{kg}^{-1}$ & 1.012 & 0.792 \\
$\mathrm{Ni}$ & $\mathrm{mg} \mathrm{kg}^{-1}$ & 3.490 & 5.716 \\
$\mathrm{~Pb}$ & $\mathrm{mg} \mathrm{kg}^{-1}$ & 199 & 1623 \\
$\mathrm{Sb}$ & $\mathrm{mg} \mathrm{kg}^{-1}$ & $<1$ & 19.94 \\
$\mathrm{Zn}$ & $\mathrm{mg} \mathrm{kg}^{-1}$ & 167 & 316 \\
$\mathrm{Benzo}(\mathrm{a})$ pyrène & $\mathrm{mg} \mathrm{kg}^{-1}$ & 0.57 & 0.47 \\
Dibenzo(ah)anthracène & $\mathrm{mg} \mathrm{kg}^{-1}$ & 0.27 & 0.10 \\
Total $\sum 16$ PAH & $\mathrm{mg} \mathrm{kg}^{-1}$ & 11.5 & 8.52 \\
Total $\sum 16$ PAH /C & $\mathrm{mg} \mathrm{kg-C}^{-1}$ & 735 & 145 \\
PCB52 & $\mathrm{g} \mathrm{kg} \mathrm{g}^{-1}$ & 0.60 & 10.32 \\
PCB180 & $\mu \mathrm{g} \mathrm{kg}^{-1}$ & 1.92 & 1.22 \\
Total $\sum 18$ PCB & $\mu \mathrm{g} \mathrm{kg}^{-1}$ & 15.30 & 48.02 \\
\hline
\end{tabular}

Bulk density weighted averages $(n=5)$. Arsenic and Mercury $<1$ $\mathrm{mg} \mathrm{kg-1}$

\section{Leaching experiments}

\section{Concentrations}

Concentrations of global parameters $(\mathrm{pH}$, conductivity, turbidity, DOC, UV absorbance and fluorescence indexes), trace metals and organic pollutants were measured in the dissolved phase of the column effluents collected under each hydraulic regime (i.e. unsaturated percolation to simulate rainfall and saturated elution to simulate river flooding) (table 3). Artificial rain and river water contained appreciable amounts of total PAH (209 and $895 \mathrm{ng} \mathrm{L}^{-1}$, respectively) and PCB (7.2 and 2.6 $\mathrm{ng} \mathrm{L}^{-1}$, respectively) but limited concentrations of trace metals. High concentrations of $\mathrm{Ca}$ and $\mathrm{Mg}$ were present in all effluent samples $\left(>100 \mathrm{mg} \mathrm{L}^{-1}\right)$. Several metals like $\mathrm{Cr}, \mathrm{Ni}, \mathrm{Pb}$ and $\mathrm{Fe}$ were not detected in the dissolved fraction of leachates, though all of them were present in the soil matrix (table 2). Neither As nor $\mathrm{Hg}$ was detected in soils and leachates. The $\mathrm{Zn}$ levels were the highest in the DEM column percolated with artificial rain $\left(356.9 \mu \mathrm{g} \mathrm{L}^{-1}\right)$ and were in the range of $\mathrm{Zn}$ roof runoff (Gromaire- 
Mertz et al. 1999). Similar levels of $\mathrm{Zn}$ in soil leachates were found by Rennert et al. (2010) in comparable experimental set-up. Significantly higher concentrations of $\mathrm{Co}, \mathrm{Cu}$ and $\mathrm{Mo}$ were observed under saturated conditions (s-DEM and s-BURN columns) compared to unsaturated percolation ( $\mathrm{u}-\mathrm{DEM}$ and $\mathrm{u}-\mathrm{BURN}$ columns). In the saturated conditions, these levels were also accompanied by higher concentration of $\mathrm{Mn}$, which may be due to the activity of manganese-reductive bacteria reducing manganese oxides and releasing associated trace metals. Such process has already been observed in soils and anaerobic sediments and was attributed to the iron- and manganese-reductive bacteria. $\mathrm{Cu}$ and $\mathrm{Zn}$ showed a low solubilisation because they were probably not associated with oxides. Indeed, several authors (Bousserrhine et al. 1999; Gounou et al. 2010; Harris-Hellal et al. 2011) have shown that in temperate soils, the organic matter constitutes the more important carrier phase for $\mathrm{Zn}$ and $\mathrm{Cu}$ than iron- and manganese oxides.

The absence of ferrous iron in collected solution can be explained by the set-up, whereby effluent exposed to ambient air was collected once a day and by the precipitation of solubilised iron given the high $\mathrm{pH}$ of the solution (Bousserrhine et al. 1999). This process was confirmed by turbidity increase and total iron concentration. The low solubilisation of manganese and associated metals in unsaturated columns can be explained by the absence of anaerobic conditions necessary for the functioning of reducing bacteria or the low activity of these bacteria.

As described by Lovley and Phillips (1986); Bousserrhine et al. (1999); and Gounou et al. (2010), the reductive bacterial activity of iron and manganese is often associated with fermentation metabolism producing organic acids. This metabolism probably explains the increase of DOC in the saturated column where a solubilisation of trace metals was observed. None of the trace metals detected in the leachate infringes the French environmental limits, nor for wastewater discharge nor for raw water for drinking water supply (Legifrance 2007, 2012).

The concentrations of organic micropollutants (PAHs and PCBs) in the eluents were situated between roof (Gromaire et al. 2014) and road runoff in the Paris metropole (Gasperi et al. 2010, 2012). Despite the high levels in the soil, the total PAH and PCB concentrations in column effluents were even lower than in the waters supplied, which indicates that these compounds were not released, but partially adsorbed onto soils during percolation.

This can be explained by their relatively low solubility, which decreases with increasing molecular weight. PAHs are likely bound to organic matter such as humic acid, and the binding capacity of humic acid is highly dictated by protonation/deprotonation. The structure of humic acid is relatively labile and the number of binding sites will depend on the $\mathrm{pH}$ of the solution. Schlautman and Morgan (1993) showed that the binding capacity of humic acid for PAHs would increase as the $\mathrm{pH}$ decreases. Thus, considering the relatively high $\mathrm{pH}$ of the solution $(\mathrm{pH} \cong 8)$, the PAHs will remain rather bound to the solids than pass to the pore water solution by binding to dissolved organic matter. Another important inorganic parameter that affects PAH solubility may be the 'salting-out' effect whereby the PAH solubility decreases as the salt concentrations increase (Oh et al. 2013). The high conductivity of the leachate, especially in unsaturated conditions, supports this hypothesis. Both effects contribute not only to the retention of PAHs in the soil but also to the adsorption of PAHs present in the eluent (Walsh et al. 2005). 
398 Table. 3 Average concentrations of global parameters, trace metals and organic micropollutants in

399 artificial rain, river water and the column effluents in dissolved fraction

\begin{tabular}{|c|c|c|c|c|c|c|c|c|}
\hline & & $L O D(*)$ & Art. Rain & River water & u-DEM & s-DEM & u-BURN & s-BURN \\
\hline Hydraulic cond. & $\mathrm{M} \mathrm{s}^{-1}$ & & - & - & 7.5E-06 & $8.3 \mathrm{E}-06$ & $1.7 \mathrm{E}-06$ & $2.0 \mathrm{E}-06$ \\
\hline $\mathrm{pH}$ & - & 0.05 & 6.96 & 8.03 & 7.65 & 7.74 & 7.78 & 7.88 \\
\hline Conductivity & $\mathrm{mS} \mathrm{cm}^{-1}$ & 0.01 & 0.04 & 0.519 & 2.55 & 2.57 & 0.98 & 0.94 \\
\hline Turbidity & NTU & 0.1 & 0.49 & 0.97 & 1.52 & 75.12 & 1.23 & 1.40 \\
\hline $\operatorname{COD} t=t$ & $\mathrm{mgO}_{2} \mathrm{~L}^{-1}$ & 2 & $<\mathrm{LOD}$ & 3.3 & 6.94 & 14.54 & 3.43 & 4.24 \\
\hline $\mathrm{DBO}_{5} t=t$ & $\mathrm{mgO}_{2} \mathrm{~L}^{-1}$ & 0.5 & $<\mathrm{LOD}$ & 3.5 & 1.8 & 6.0 & 0.7 & 1.6 \\
\hline DOC & $\mathrm{mgC} \mathrm{L}^{-1}$ & 0.1 & 0.10 & 2.0 & 9.10 & 17.31 & 5.02 & 4.72 \\
\hline SUVA & $\mathrm{L} \mathrm{mgC}^{-1}$ & 0.1 & 1.00 & 2.65 & 4.00 & 2.70 & 2.14 & 2.06 \\
\hline HIX & - & - & 0.22 & 3.49 & 15.28 & 7.52 & 6.99 & 9.28 \\
\hline BIX & - & - & 0.87 & 0.77 & 0.59 & 0.60 & 0.88 & 0.87 \\
\hline $\mathrm{Al}$ & $\mu \mathrm{g} \mathrm{L}^{-1}$ & 8.0 & 17.10 & 9.77 & 18.3 & 19.0 & 21.9 & 21.7 \\
\hline $\mathrm{Co}$ & $\mu \mathrm{g} \mathrm{L}^{-1}$ & 0.42 & $<\mathrm{LOD}$ & $<\mathrm{LOD}$ & $<\mathrm{LOD}$ & 5.19 & $<\mathrm{LOD}$ & $<\mathrm{LOD}$ \\
\hline $\mathrm{Cu}$ & $\mu \mathrm{g} \mathrm{L}^{-1}$ & 1.2 & $<\mathrm{LOD}$ & $<\mathrm{LOD}$ & 7.12 & 16.4 & $<\mathrm{LOD}$ & $<\mathrm{LOD}$ \\
\hline $\mathrm{Mg}$ & $\mu \mathrm{g} \mathrm{L}^{-1}$ & 5.5 & 396 & 3875 & 7296 & 7789 & 5069 & 5749 \\
\hline $\mathrm{Mn}$ & $\mu \mathrm{g} \mathrm{L}^{-1}$ & 11 & 12.35 & 11.15 & 1114.0 & 6826.9 & 183.7 & 490.4 \\
\hline Мo & $\mu \mathrm{g} \mathrm{L}^{-1}$ & 4.5 & 11.20 & 8.23 & 11.5 & 25.2 & 5.53 & 8.16 \\
\hline $\mathrm{Sb}$ & $\mu \mathrm{g} \mathrm{L}^{-1}$ & 7.5 & $<\mathrm{LOD}$ & $<\mathrm{LOD}$ & $<\mathrm{LOD}$ & $<\mathrm{LOD}$ & $<\mathrm{LOD}$ & 52.8 \\
\hline $\mathrm{Si}$ & $\mu \mathrm{g} \mathrm{L}^{-1}$ & 2.7 & 1586 & 1944 & 13683 & 12195 & 5634 & 5099 \\
\hline $\mathrm{Zn}$ & $\mu \mathrm{g} \mathrm{L}^{-1}$ & 2.6 & 31.01 & 37.59 & 356.9 & 108.6 & 26.8 & 33.7 \\
\hline $\operatorname{DBahA}(* *)$ & $\mu \mathrm{g} \mathrm{L}^{-1}$ & 0.1 & 0.125 & 0.115 & 0.106 & 0.087 & 0.182 & 0.211 \\
\hline$\Sigma 16$ PAH & $\mu \mathrm{g} \mathrm{L}^{-1}$ & 2 & 209 & 895 & 118 & 199 & 185 & 172 \\
\hline PCB52 & $\mu \mathrm{g} \mathrm{L}^{-1}$ & 0.1 & 1.084 & 0.188 & 0.279 & 0.173 & 0.256 & 0.178 \\
\hline$\Sigma 18 \mathrm{PCB}$ & $\mu \mathrm{g} \mathrm{L}^{-1}$ & 0.1 & 7.239 & 2.581 & 4.028 & 3.033 & 2.772 & 2.324 \\
\hline
\end{tabular}

u-DEM, demolition waste percolated by artificial rain; s-DEM, demolition waste, saturated and eluted with river water; u-BURN, river bed contaminated by electronic equipment burning, percolated by artificial rain; s-BURN, contaminated river bed, saturated and eluted with river water. The river contained $34 \mathrm{mgSO}_{4} \mathrm{~L}^{-1}$ and $18 \mathrm{mgNO}_{3} \mathrm{~L}^{-1}$, while the rain contained 1.32 and $1.22 \mathrm{mg} \mathrm{L}^{-1}$, respectively. **dibenzo(ah)anthracene

* $L O D$ limit of detection; $\mathrm{Cr}$ : $1.1 \mu \mathrm{g} \mathrm{L}^{-1}$; Fe: $1.3 \mu \mathrm{g} \mathrm{L}^{-1}$ and $\mathrm{Pb}: 4.8 \mu \mathrm{g} \mathrm{L} \mathrm{g}^{-1}$ are not shown as all values were below LOD

400

401

402

403

404

405

406

407

408

409

410

411

412

413

414

415

416

417

The usual evolution for long-term columns experiments under aerobic condition is a decay of the component concentration in the leachate (Cappuyns and Swennen 2008; Naka et al. 2016). This can be globally seen with conductivity and DOC in Figure 6. However, the intermittence of hydraulic regimes applied (percolation followed by a longer rest period) combines the physico-chemical processes like desorption and dissolution with microbiological transformation. For example, under flooding conditions, the dissolution processes, illustrated by turbidity and conductivity, are superposed in the beginning by bacterial reduction processes resulting in a stronger metal release. Figure 6 illustrates the influence of hydraulic conditions on the organic matter release especially for the DEM soil, where an initial fast DOC increase can be observed under saturated conditions and the saturated release of $17.3 \mathrm{mgC} \mathrm{m}^{-2} \mathrm{~mm}^{-1}$ was thereby $47 \%$ higher than the unsaturated one. For the BURN soil, there was no difference. This difference might be due to higher mineralisation rate in the anoxic conditions as was observed by other authors (Bastviken et al. 2004). This process was accompanied by aromaticity (HIX) increase. In BURN soil, it was faster than in DEM soil probably due to leaching of burned material in the first and humic substances in the latter (Huguet et al. 2009, 2010).

Though the heavy metal content was much higher in the BURN soil than in the DEM soil, the levels 
418 of $\mathrm{Cu}$ and $\mathrm{Zn}$ were lower in the BURN zone effluents than in the DEM effluents. This could be 419 explained by the difference in soil composition, trace metal association to soil components and 420 bacterial activity. $\mathrm{Cu}$ and $\mathrm{Zn}$ were probably more associated to iron and manganese oxides in DEM samples than in BURN ones. The polluted upper silt soil released only slowly the heavy metals due to presence of carbonates (higher $\mathrm{pH}$ ), better retaining the pollution before passing to lower levels. An initial increase of $\mathrm{Cu}$ was observed due to liberation of easily bound metals linked to organic matter, alumino-silicates and or Fe/Mn hydroxides, followed by decay (Figure 6). Similar results were reported by Gounou et al. (2010) showing that in anaerobic sediment, the bacterial reduction of iron oxides was concomitant with trace metal solubilisation. The flux of zinc and copper in the recomposed DEM soil seemed therefore to be related to organic matter release $\left(r^{2}=0.88\right.$, respectively, $r^{2}=0.98$, $\mathrm{p}>0.05)$. The gradual transformation of organic matter can be seen from the increase of the HIX fluorescence index. Under saturated conditions, zinc and copper were thereby more linked to the aromatic components HIX $\left(r^{2}=0.95\right.$, respectively, $\left.r^{2}=0.82, p>0.05\right)$ than BIX. No correlation was observed with HIX under unsaturated conditions. This behaviour was not observed for the BURN soil. Both metals showed correlation with manganese under aerobic conditions $\left(r^{2}>0.6, \mathrm{p}>0.05\right)$ for DEM and BURN soil but not under the anoxic conditions.

The hydraulic conditions influenced the redox conditions and therefore the metal release. The major indicator of redox conditions is iron, not soluble under oxic conditions (unsaturated percolation), but soluble under anoxic conditions (saturated flow). No dissolved iron was directly detected in the leachates (Table 3); however, iron was detected in colloidal form in the s-DEM effluents after 2 days of experiment and stabilised after 10 days at a level of $9.7 \mathrm{mg} \mathrm{L}^{-1}$. Dissolved iron leached from the saturated column under anoxic conditions and precipitated afterwards as colloids in the sampling bottle, where it was exposed to aerobic conditions. This precipitation of iron in amorphous form has been widely described for anaerobic environments with high $\mathrm{pH}$ and identified as the reason for trace metal precipitation (Bousserrhine et al. 1999; Gounou et al. 2010; Harris-Hellal et al. 2011). The initial iron solubilisation was also accompanied by $\mathrm{Cu}$ and $\mathrm{Zn}$ release. $90 \%$ of copper and $20 \%$ of zinc were hereby present in particulate form, trapped in the colloids. The decrease of $\mathrm{Al}, \mathrm{Cu}$ and $\mathrm{Zn}$ concentrations at the end of the experiment under saturated conditions can be explained by the formation of metallic sulphides following bacterial sulphate-reductive activity as has been reported by Bousserrhine and Gounou (Bousserrhine et al. 1999; Gounou et al. 2010).

Regarding PAHs and PCBs, there was no significant trend in the leachate concentrations of the four columns. Comparable levels of PAHs were found by Azah et al. (2017) in batch extraction of storm water sediments with artificial rain. Nevertheless, the dust used had a PAH content ten times lower than the soils HC and MX. The difference is probably due to the hydraulic conditions of batch experiments, high specific surface of dust particles and the acidity of rain, used by Azah (2017). 

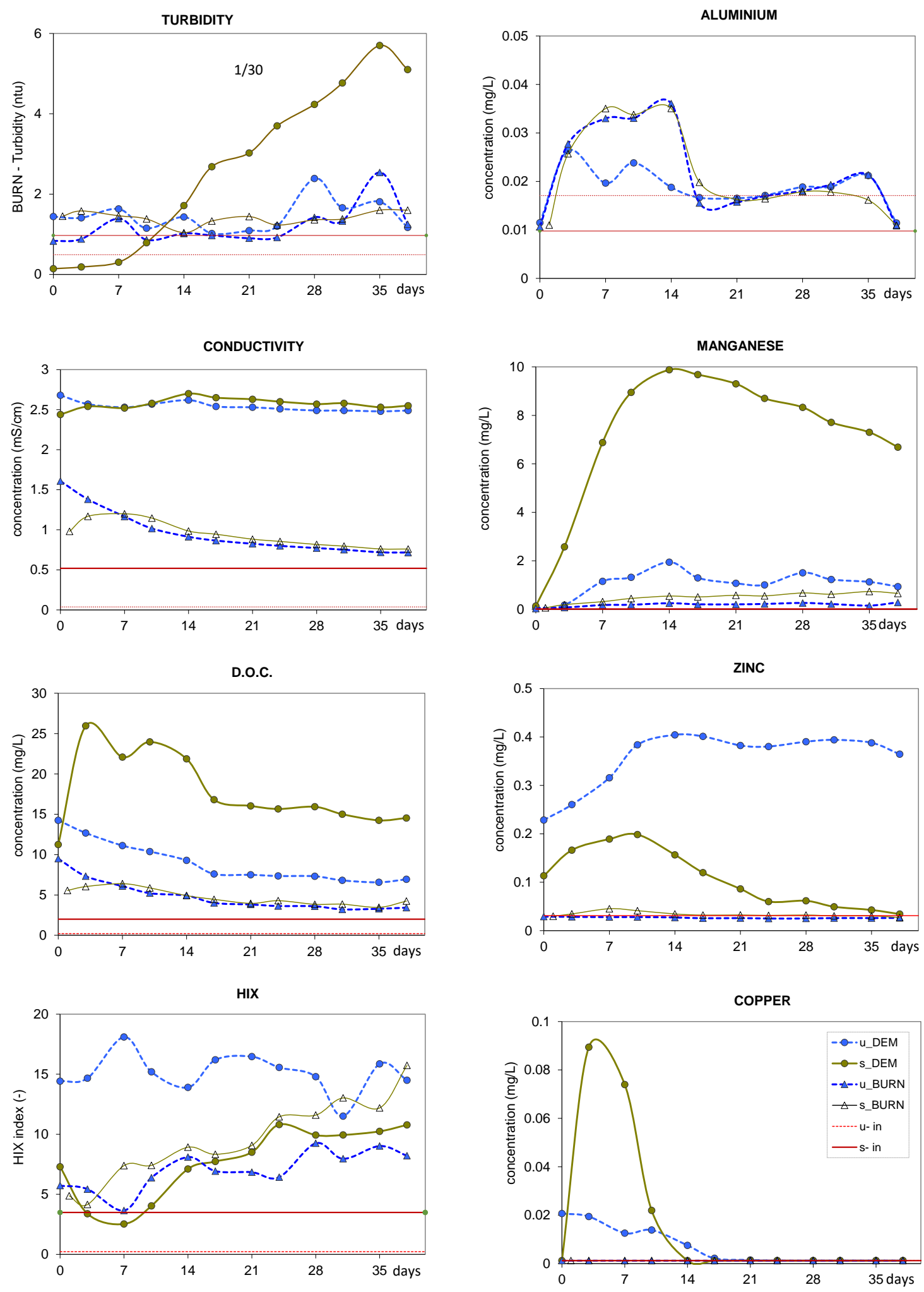

Fig. 6 Evolution of leachate concentrations $(<0.45 \mu \mathrm{m})$. Straight red lines represent the initial eluent concentration (rain and river water). The dashed lines correspond to experiments with artificial rainwater, and the solid lines corresponds to experiments with river water, whereby the dots represent the soil recomposed from contaminated demolition waste (DEM) and triangles represent burning zone soil (BURN). The iron, not shown, was only detected in the saturated DEM soil, at same level as 462 manganese but in the form of colloids 


\section{Effect of hydraulic conditions on pollutant release}

PCA A principal component analysis (PCA) was performed to better understand the relationships between all measured parameters. The PCA results show that the four types of columns can be clearly differentiated according to the soil types and hydraulic conditions, based on the whole set of analytical results (Figure 7).
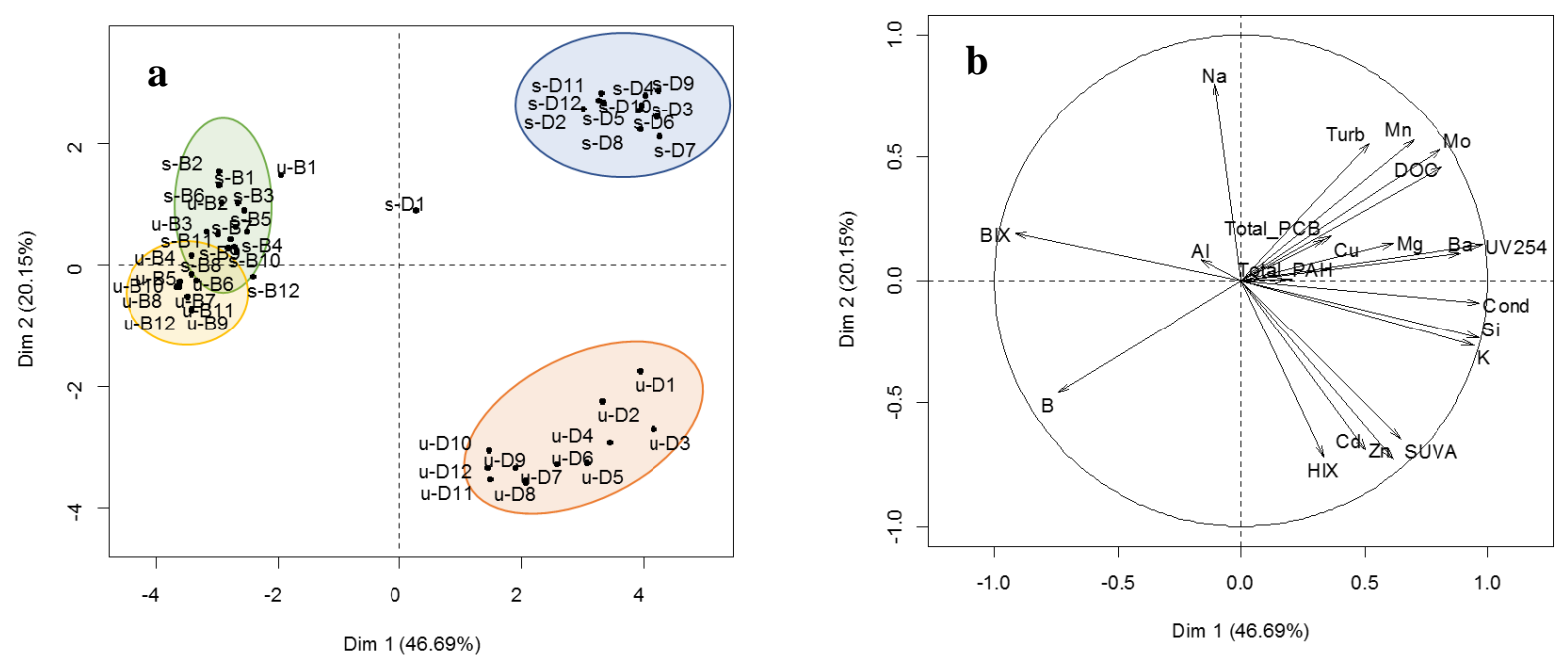

469

470

471

472

473

474

475

476

477

478

479

480

481

482

483

484

485

486

487

488

489

490

491

492

493

494

495

496

497

Fig. 7 PCA for the overall set of concentration data. D, DEM; B, BURN. a scores plot; b loadings plot

PCA analysis differentiated clearly by the first dimension, BURN soil on the left (negative portion of the $\mathrm{X}$ axis) and the DEM soil on the right side (positive portion of the $\mathrm{X}$ axis). The first dimension was mainly driven by the conductivity (capacity of dissolution), organic matter (DOC) and its aromaticity type (UV254, BIX) as well as the metal content. The samples from the BURN zone were characterised by higher values of BIX fluorescence index and boron and sodium concentrations, while the samples from the DEM zone were characterised by higher conductivity, DOC, copper, manganese and zinc, as well as the dibenzo(ah)anthracene and benzo(a)anthracene inter alia.

The second PCA dimension was mainly driven by sodium concentration followed by HIX index and trace metals $\mathrm{Zn}$ and $\mathrm{Cd}$, thus indicating that the flooding condition favoured the release of sodium in leachates. The differentiation between the two hydraulic conditions was more pronounced for the DEM samples. From these samples, Mn and Mo were mainly released under flooding conditions, while $\mathrm{Cd}$ and $\mathrm{Zn}$ releases were favoured by the rainfall hydraulic regime.

Fluxes To evaluate the overall contribution of hydraulic conditions and types of soil to the pollutant release, total fluxes were calculated from concentrations and flows. The incoming fluxes entering the columns were compared to the outcoming fluxes (Figure 8). Three types of behaviour could be observed: (i) no leaching whereby the outcoming flux was globally equal to the applied flux (Co, $\mathrm{Cd}$, $\mathrm{Al}, \mathrm{Na}$ ); (ii) a medium leaching, whereby outcoming flux was globally ten times the incoming flux $(\mathrm{Cu}, \mathrm{Si}, \mathrm{Zn})$; and (iii) a pronounced leaching of metals above quotient of 100 (Mn, K, B).

The rainfall unsaturated condition had a stronger leaching effect than the saturated condition regarding $\mathrm{Zn}, \mathrm{Mg}, \mathrm{K}$, and B. This behaviour was even more pronounced for the DEM soil than for the BURN soil. The rain condition maintains an open soil structure with presence of oxygen and that river flooding condition tends to modify the soil structure lowering the permeability and creating anoxic 
conditions. The anoxic conditions may diminish the solubility of metals by forming sulphides, which could explain the higher release of several metals $(\mathrm{Zn}, \mathrm{Mg}, \mathrm{K}, \mathrm{B})$ under unsaturated conditions. On the contrary, under reducing conditions, high-valent iron and manganese present in soils are reductively dissolved via a number of alternative abiotic and microbial pathways (Roden and Wetzel 2002). Fe(III) can act as a terminal electron acceptor during microbially mediated decomposition of organic matter, forming soluble ferrous ion $\left(\mathrm{Fe}^{2+}\right.$ ) (Lovley and Phillips 1986; Bousserrhine et al. 1999). This picture becomes more complex, if we take into account the presence of nitrate and sulphate in the river water and $\mathrm{Fe}^{2+}$ and $\mathrm{Mn}^{2+}$ as potential electron donors making their oxidation possible, through nitrate reduction (Pyzola 2013). The higher fluxes of Fe and $\mathrm{Mn}$ and lower flux of $\mathrm{Zn}$ in the s-DEM leachate (saturated conditions), compared to the u-DEM leachate (unsaturated conditions), are in accordance with these processes.
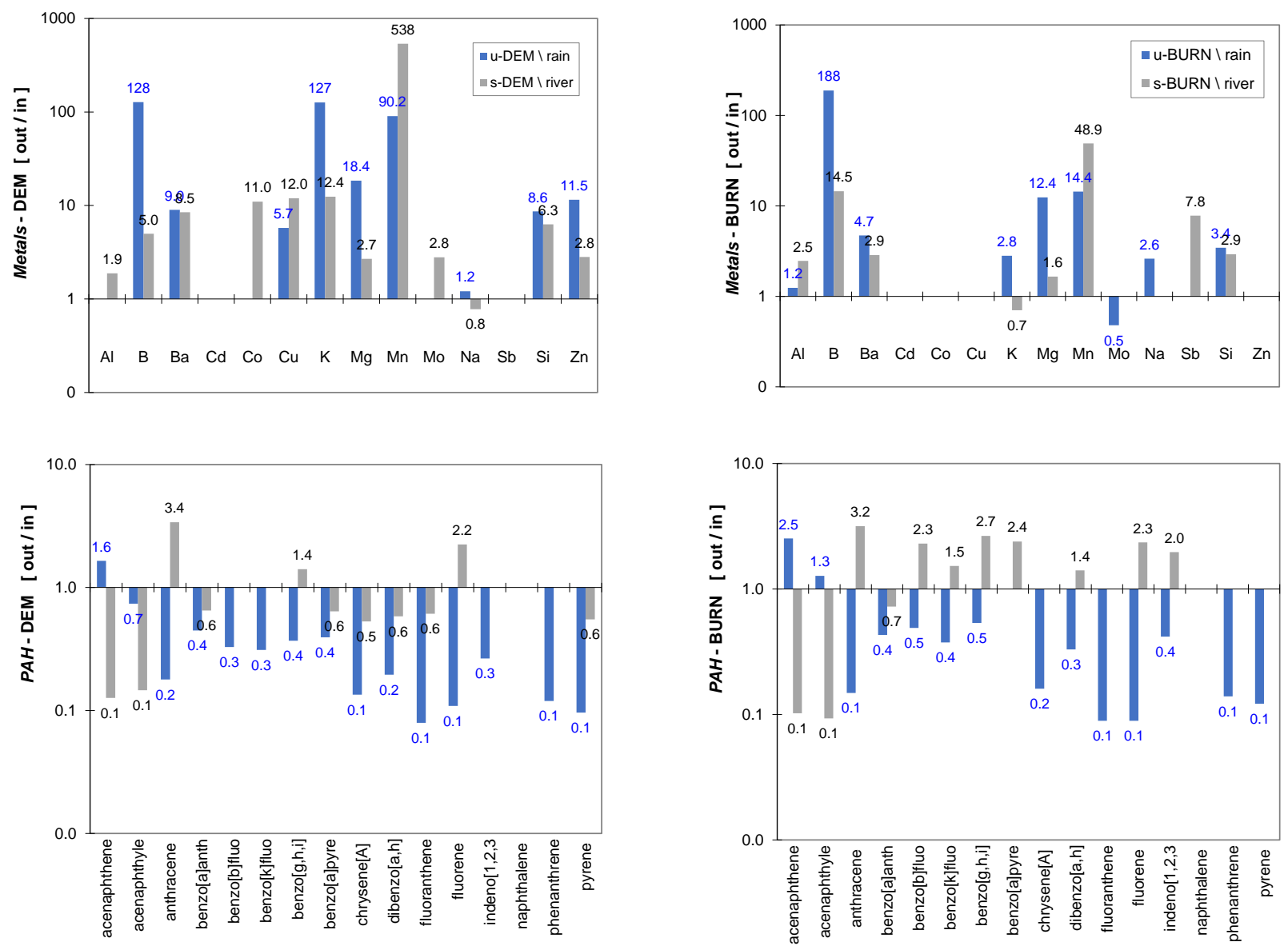

Fig. 8 Retention and release of different micropollutants as the ratio of the outcoming to incoming flux. A value below 1 means retention and value above 1 means release. Values between 0.8 and 1.2, estimates are not significatively different from 1 and are not shown. PCBs are not shown as all species were retained in both substrates. Saturated conditions in grey, unsaturated in blue

As described before, the BURN soil exhibited the highest contamination by metals, but its natural clay structure and high organic matter content immobilised the pollution and presented in fine little leaching in the different hydraulic conditions. The differences between the saturated and unsaturated flows regarding the leaching of metals were rather due to the existence of different redox conditions than to the difference in residence time (i.e. ratio of saturated pore volume and flow). Neither the higher water content of saturated columns compared to unsaturated nor the higher porosity of BURN 
soil compared to DEM soil impacted the release of micropollutants. The low importance of flow velocity was also reported by Naka (Naka et al. 2016).

Contrary to metals, the change in hydraulic conditions had a clear impact on the PAH retention. The retention of all PAH was high (flux ratio always $<1$ except for anthracene and fluorene) under saturated conditions in both the DEM and the BURN soils (s-DEM and s-BURN in Figure 7). In saturated conditions (i.e. river flood condition), PAH flux ratio was closer or higher to 1, especially for the BURN soil (i.e. u-BURN). These results indicate that the rain (acidity), combined with unsaturated flow, created conditions favourable for retention of $\mathrm{PAH}$, while in saturated conditions, PAH were more released especially in the BURN soil, most probably due to desaturation of the burning layer. PCB exhibited a similar behaviour than PAH with a lower difference between the two hydraulic conditions.

Pollutants fluxes can also be expressed in $\mathrm{g} \mathrm{m}^{-2} \mathrm{year}^{-1}$ or $\mathrm{kg} \mathrm{ha}^{-2} \mathrm{year}^{-1}$. If we focus on zinc and copper, there was only a net flux from the DEM soil. Taking the average annual precipitation on the region of $650 \mathrm{~mm}$, dissolved zinc showed a flux of $2.1 \mathrm{~kg} \mathrm{ha}^{-2}$ year $^{-1}$ for the rainfall condition (u-DEM) decreasing to $0.36 \mathrm{~kg} \mathrm{ha}^{-2}$ year $^{-1}$ for the river flood condition (s-DEM). Compared to the annual atmospheric deposition of zinc in the Paris region of 0.45 to $1.2 \mathrm{~kg} \mathrm{ha}^{-2}$ year $^{-1}$ (Azimi et al. 2005), these values may impact significantly the background levels for zinc. Dissolved copper behaved differently with $0.038 \mathrm{~kg} \mathrm{ha}^{-2}$ year $^{-1}$ for u-DEM increasing to $0.078 \mathrm{~kg} \mathrm{ha}^{-2}$ year $^{-1}$ for s-DEM. $_{\text {. }}$ These fluxes were significatively higher if we take into account the flux of particulate copper associated to iron, and would be close to values of the atmospheric deposition of 0.1 to 0.2 $\mathrm{kg} \mathrm{ha}^{-2}$ year $^{-1}$ reported by Azimi (Azimi et al. 2005) and Gasperi (Gasperi et al. 2014).

\section{Conclusions}

The studied soils were moderately to strongly polluted, exceeding the French environmental limits (MEDDM et al. 2009). The DEM soil, marked by demolition disposal over the whole depth, was coarser with higher permeability. The BURN soil was finer and only impacted in the upper soil, with undisturbed layers below. The DEM soil was moderately polluted with trace metals over the whole depth, while the BURN soil was extremely polluted ( $\mathrm{Zn}, \mathrm{Cu}$ and $\mathrm{Pb}$ of several $\mathrm{g} \mathrm{kg}^{-1}$ with pronounced presence of PAH and PCB) only in the first $20 \mathrm{~cm}$ of the soil profile.

The results showed that the intermittence of hydrological regime increased the pollutant release compared to continuous exposition, though the type and structure of soil were of greater importance than the condition of saturation applied. The leachates of the DEM soil were characterised by higher conductivity and DOC content, indicating dissolution and desorption as key processes in pollutant release. Though the BURN soil was 10 times more contaminated with trace metals than the DEM soil, only the latter released copper, zinc and cobalt in significant amounts. Iron- and manganese-reducing bacteria were implicated in the solubilisation of trace metals under anaerobic conditions through the production of soluble iron and manganese oxides and the release of associated metals. The concentrations of pollutants in the leachates were close to those of road runoff and for zinc and copper far above the European standards for receiving water bodies (CEE 2008). According to literature (Seidl et al. 1998; Baun et al. 2008), their peak concentration could eventually generate an acute exposition level if directly released to aquatic ecosystems.

Statistical analysis of the data showed more pronounced differences between the two soil types than between the two hydrological regimes studied (i.e., rainfall and river flooding). Hydrology was still a significant driver especially for the DEM soil and to a lesser extent for the BURN soil. Unsaturated conditions (rainfall) favoured dissolution of silicates and zinc release, while the application of 
saturated conditions (river flooding) created reductive environment liberating iron and manganese and most probably linked copper. PAH remained adsorbed onto soil in unsaturated conditions but slightly released under saturated flow in the BURN soil. The PCB did not release. No significant relationship was observed between the organic micropollutants and the organic matrix indicators (HIX, BIX and aromaticity), suggesting that these parameters and the humic substances present in the soil matrix were not directly linked to the behaviour of these pollutants. The only correlation for these parameters was found for zinc and copper in the u-DEM soil suggesting their release under anaerobic condition to be also linked to humic matter transformation.

Based on the presented leaching experiments, it can be concluded that under actual field conditions, the high levels of PAHs, PCBs and trace metals present upon natural silty sedimentary soils (BURN) do not present an immediate risk for the surrounding aquatic ecosystem because of strong associations between organic pollutants, soil particles, metals and iron or manganese oxides. During flood periods, a limited release of PAHs can be expected. On the contrary, the less contaminated demolition disposal (DEM) presents a moderate risk of zinc and copper mobilisation under actual hydrological conditions (i.e. rain events), doubling the atmospheric wet weather deposition. Overall, a flooding condition would produce a lower risk of trace metal release than rainfall but will cause a cumulative effect.

The general implication of the results obtained is that long-term risk assessment of contained soil should be done with stratified media, applying hydrological conditions (saturation, periodicity, duration of exposition...) as close as possible to field conditions rather than using standard batch tests with fixed L/S ratio. The approach used allowed to identify biogeochemical transformations and to estimate more adequately the fluxes which could be released to the environment.

The experimental set-up showed to be adequate to study different hydrological conditions of stratified soil contamination and allowed to simulate in situ conditions and obtain more realistic results than batch experiments or full mixed columns. However, some improvements might improve the overall sensitivity of the system, such as airtight sampling bags preventing the oxidation and transformation of collected samples. Moreover, parallel measurements of auxiliary parameters like in- and outcoming nitrate, sulphate and BOD5 would give better information about the existing microbiological processes.

\section{Supplementary Information}

The online version contains supplementary material available at https://doi.org/10.1007/s11356-02115491-0.

\section{Acknowledgements}

The authors acknowledge the Conseil départmental Val-de-Marne for their indispensable assistance during the fieldwork and Olivier Fouché for the field permeability data.

\section{Author contribution}

Conceptualization: Martin Seidl. Methodology: Remi Mazerolle, Martin Seidl and Julien Le Roux. Investigation: Remi Mazerolle and Martin Seidl. Formal analysis: Martin Seidl and Julien Le Roux. Writing, original draft preparation: Martin Seidl. Writing, review and editing: Martin Seidl, Julien Le Roux and Noureddine Bousserrhine. Funding acquisition: Martin Seidl and Noureddine Bousserrhine. Resources: Martin Seidl, Julien Le Roux and Noureddine Bousserrhine. Supervision: Martin Seidl

\section{Funding}


622 The authors acknowledge the Region Ile-de-France for its financial support to the REFUJ project, society (PICRI).

\section{Data availability}

All major data generated during this study are included in the published article. Complementary data are available from the corresponding author on request.

\section{Declarations}

Ethics approval Not applicable

Consent to participate Not applicable

Consent for publication All authors consent to publish

Competing interests The authors declare no competing interests

\section{References}

ADEME (2014) Taux d'utilisation et coûts des différentes techniques et filières de traitement des sols et des eaux souterraines pollués en France - Synthèse des données 2012. http://www.ademe.fr/sites/default/files/assets/documents/84580_rapport_taux_couts_traitem ents_sols_eaux.pdf. Accessed 17 Feb 2016

Adinsoft (2018) Statistical software \& data analysis add-on for Excel | XLSTAT 2020. Version 2018.7 Build 54791URL https://www.xlstat.com/en/

AFNOR (2002) NF EN 12457-4 - Caractérisation des déchets - Lixiviation - Essai de conformité pour lixiviation des déchets fragmentés et des boues - Partie 4 : essai en bâchée unique avec un rapport liquide/solide de 10 1/kg et une granularité inférieure à 10 mm (sans ou avec réduction de la granularité)

AFNOR (2005) Qualité de l'eau, 7eme édition. AFNOR

APHA, AWWA, WEF, et al (2012) Standard Methods for the Examination of Water and Wastewater, 22 edition. American Public Health Association, American Water Works Association and Water Environment Federation, Washington, DC

ATSDR, USDHHS (2000) Toxicological profile for polychlorinated biphenyls (PCBs). Agency for Toxic Substances and Disease Registry, Atlanta, Georgia

Azah E, Kim H, Townsend T (2017) Assessment of direct exposure and leaching risk from PAHs in roadway and stormwater system residuals. Science of The Total Environment 609:58-67. https://doi.org/10.1016/j.scitotenv.2017.07.136

Azimi S, Rocher V, Garnaud S, et al (2005) Decrease of atmospheric deposition of heavy metals in an urban area from 1994 to 2002 (Paris, France). Chemosphere 61:645-651. https://doi.org/10.1016/j.chemosphere.2005.03.022

Baize D (2000) Teneurs totales en «métaux lourds » dans les sols français résultats généraux du programme ASPITET. Courrier de l'environnement de l'INRA n³9, février:39-54 
Bastviken D, Persson L, Odham G, Tranvik L (2004) Degradation of dissolved organic matter in oxic and anoxic lake water. Limnology and Oceanography 49:109-116. https://doi.org/10.4319/lo.2004.49.1.0109

Baun A, Seidl M, Scholes L, et al (2008) Chap. 20: Application of a battery of biotests for toxicity characterization of stormwater. In: Thévenot DR (ed) DayWater: Adaptive Decision Support System for Integrated Urban Stormwater Control. IWA Publishers, pp 207-213

Bern CR, Walton-Day K, Naftz DL (2019) Improved enrichment factor calculations through principal component analysis: Examples from soils near breccia pipe uranium mines, Arizona, USA. Environmental Pollution 248:90-100. https://doi.org/10.1016/j.envpol.2019.01.122

Bousserrhine N, Gasser UG, Jeanroy E, Berthelin J (1999) Bacterial and chemical reductive dissolution of Mn-, Co-, Cr-, and Al-substituted goethites. Geomicrobiol J 16:245-258. https://doi.org/10.1080/014904599270622

Bressy A, Gromaire M-C, Lorgeoux C, Chebbo G (2011) Alkylphenols in atmospheric depositions and urban runoff. Water Science and Technology 63:671-9. https://doi.org/10.2166/wst.2011.121

Camobreco VJ, Richards BK, Steenhuis TS, et al (1996) Movement of heavy metals through undisturbed and homogenised soil columns. Soil Science 161:740-750

Cappuyns V, Swennen R (2008) The Use of Leaching Tests to Study the Potential Mobilization of Heavy Metals from Soils and Sediments: A Comparison. Water Air Soil Pollut 191:95-111. https://doi.org/10.1007/s11270-007-9609-4

CEE (2008) Directive 2008/105/CE du Parlement européen et du Conseil du 16 décembre 2008 établissant des normes de qualité environnementale dans le domaine de l'eau, modifiant et abrogeant les directives du Conseil 82/176/CEE, 83/513/CEE, 84/156/CEE, 84/491/CEE, 86/280/CEE et modifiant la directive 2000/60/CE. Journal officiel de l'Union européenne OJ L:

Clapp RB, Hornberger GM (1978) Empirical equations for some soil hydraulic properties. Water Resour Res 14:601-604. https://doi.org/10.1029/WR014i004p00601

Crone M (2001) Diagnostic de sols pollués par des hydrocarbures aromatiques polycycliques (HAP) a l'aide de la spectrophotométrie UV. Ecole Nationale Supérieure des Mines de SaintEtienne; INSA de Lyon

Cueff S, Alletto L, Bourdat-Deschamps M, et al (2020) Water and pesticide transfers in undisturbed soil columns sampled from a Stagnic Luvisol and a Vermic Umbrisol both cultivated under conventional and conservation agriculture. Geoderma 377:114590. https://doi.org/10.1016/j.geoderma.2020.114590

Dermont G, Bergeron M, Mercier G, Richer-Laflèche M (2008) Soil washing for metal removal: A review of physical/chemical technologies and field applications. Journal of Hazardous Materials 152:1-31. https://doi.org/10.1016/j.jhazmat.2007.10.043

Dingman SL (2015) Physical hydrology, 3. ed. Waveland Press, Long Grove, Ill 
DRIEE (2015) Plan de gestion des risques d'inondation (PGRI) du bassin Seine-Normandie 20162021

DRIEE (2018) Inondations - DRIEE Ile-de-France. http://www.driee.ile-de-france.developpementdurable.gouv.fr/inondations-r183.html. Accessed 3 Nov 2018

Du Laing G, Rinklebe J, Vandecasteele B, et al (2009) Trace metal behaviour in estuarine and riverine floodplain soils and sediments: A review. Science of The Total Environment 407:3972-3985. https://doi.org/10.1016/j.scitotenv.2008.07.025

Dunne T, Leopold LB (1978) Water in Environmental Planning, 1st edition. W. H. Freeman, San Francisco

ENPF (2017) Espace Naturel de la Pierre-Fitte. https://fr-fr.facebook.com/EspaceNaturelPierreFitte/. Accessed 29 Aug 2017

Fang W, Wei Y, Liu J, et al (2016) Effects of aerobic and anaerobic biological processes on leaching of heavy metals from soil amended with sewage sludge compost. Waste Management 58:324-334. https://doi.org/10.1016/j.wasman.2016.07.036

Gasperi J, Gromaire MC, Kafi M, et al (2010) Contributions of wastewater, runoff and sewer deposit erosion to wet weather pollutant loads in combined sewer systems. Water Research 44:5875-5886. https://doi.org/10.1016/j.watres.2010.07.008

Gasperi J, Sebastian C, Ruban V, et al (2014) Micropollutants in urban stormwater: occurrence, concentrations, and atmospheric contributions for a wide range of contaminants in three French catchments. Environmental Science and Pollution Research 21:5267-5281. https://doi.org/10.1007/s11356-013-2396-0

Gasperi J, Zgheib S, Cladière M, et al (2012) Priority pollutants in urban stormwater: Part 2 - Case of combined sewers. Water Research 46:6693-6703. https://doi.org/10.1016/j.watres.2011.09.041

Gonzalez M, Mitton FM, Miglioranza KSB, Peña A (2019) Role of a non-ionic surfactant and carboxylic acids on the leaching of aged DDT residues in undisturbed soil columns. J Soils Sediments 19:1745-1755. https://doi.org/10.1007/s11368-018-2172-3

Gounou C, Bousserrhine N, Varrault G, Mouchel J-M (2010) Influence of the Iron-Reducing Bacteria on the Release of Heavy Metals in Anaerobic River Sediment. Water Air Soil Pollut 212:123-139. https://doi.org/10.1007/s11270-010-0327-y

Gromaire M-C, Lamprea-Bretaudeau K, Seidl M, Mirande-Bret C (2014) Organic micropollutants in roof runoff - a study of the emission / retention potential of green roofs. In: ICUD 2014,13th International Conference on Urban Drainage, Sarawak, Malaysia, 7-12 September 2014

Gromaire-Mertz MC, Garnaud S, Gonzalez A, Chebbo G (1999) Characterisation of urban runoff pollution in Paris. Water Science and Technology 39:1-8. https://doi.org/10.1016/S02731223(99)00002-5

Guittard A, et al. (2013) Evaluation quantitative des risques sanitaires (EQRS) Prestation codifiée A320 selon NF X31-620 
Harris-Hellal J, Grimaldi M, Garnier-Zarli E, Bousserrhine N (2011) Mercury mobilisation by chemical and microbial iron oxide reduction in soils of French Guyana. Biogeochemistry 103:223-234. https://doi.org/10.1007/s10533-010-9457-y

Holoubek I, Dušek L, Sáňka M, et al (2009) Soil burdens of persistent organic pollutants - Their levels, fate and risk. Part I. Variation of concentration ranges according to different soil uses and locations. Environmental Pollution 157:3207-3217. https://doi.org/10.1016/j.envpol.2009.05.031

Huguet A, Vacher L, Relexans S, et al (2009) Properties of fluorescent dissolved organic matter in the Gironde Estuary. Organic Geochemistry 40:706-719. https://doi.org/10.1016/j.orggeochem.2009.03.002

Huguet A, Vacher L, Saubusse S, et al (2010) New insights into the size distribution of fluorescent dissolved organic matter in estuarine waters. Organic Geochemistry 41:595-610. https://doi.org/10.1016/j.orggeochem.2010.02.006

ISO (2019) ISO 21268-3 Soil quality — Leaching procedures for subsequent chemical and ecotoxicological testing of soil and soil-like materials - Part 3: Up-flow percolation test

Jin Z, Zhang Z, Zhang H, et al (2015) Assessment of lead bioaccessibility in soils around lead battery plants in East China. Chemosphere 119:1247-1254. https://doi.org/10.1016/j.chemosphere.2014.09.100

Kafi M, Gasperi J, Moilleron R, et al (2008) Spatial variability of the characteristics of combined wet weather pollutant loads in Paris. Water Research 42:539-549. https://doi.org/10.1016/j.watres.2007.08.008

Legifrance (1998) Arrêté du 8 janvier 1998 fixant les prescriptions techniques applicables aux épandages de boues sur les sols agricoles pris en application du décret no 97-1133 du 8 décembre 1997 relatif à l'épandage des boues issues du traitement des eaux usées. JORF $\mathrm{n}^{\circ} 26$ du 31 janvier 1998 page 1563

Legifrance (2007) Arrêté du 11 janvier 2007 relatif aux limites et références de qualité des eaux brutes et des eaux destinées à la consommation humaine mentionnées aux articles R. 1321-2, R. 1321-3, R. 1321-7 et R. 1321-38 du code de la santé publique. JORF JORF $n^{\circ} 31 \mathrm{du}$ 06/02/2007 texte numéro 17

Legifrance (2012) Arrêté du 26 mars 2012 relatif aux prescriptions générales applicables aux installations classées relevant du régime de l'enregistrement au titre de la rubrique $\mathrm{n}^{\circ} 2710-2$ (installations de collecte de déchets non dangereux apportés par leur producteur initial) de la nomenclature des installations classées pour la protection de l'environnement - Article 35 | Legifrance. JORF

Li J, Jia C, Lu Y, et al (2015) Multivariate analysis of heavy metal leaching from urban soils following simulated acid rain. Microchemical Journal 122:89-95. https://doi.org/10.1016/j.microc.2015.04.015

Lovley DR, Phillips EJP (1986) Organic Matter Mineralization with Reduction of Ferric Iron in Anaerobic Sediments. Appl Environ Microbiol 51:683-689 
MEDDM, DGALN, DEB (2009) Recueil de textes sur l'assainissement : Textes techniques relatifs à l'épandage des boues d'épuration résultant du traitement des eaux usées domestiques. Ministère de l'écologie, de l'énergie, du développement durable et de la mer (MEDDM), Direction générale de l'aménagement, du logement et de la nature (DGALN) Direction de l'eau et de la biodiversité (DEB) Bureau de la lutte contre les pollutions domestiques et industrielles

Motelay-Massei A, Ollivon D, Garban B, et al (2004) Distribution and spatial trends of PAHs and PCBs in soils in the Seine River basin, France. Chemosphere 55:555-565. https://doi.org/10.1016/j.chemosphere.2003.11.054

Naka A, Yasutaka T, Sakanakura H, et al (2016) Column percolation test for contaminated soils: Key factors for standardization. Journal of Hazardous Materials 320:326-340. https://doi.org/10.1016/j.jhazmat.2016.08.046

Nasri B, Fouché O, Ramier D (2015) Monitoring infiltration under a real on-site treatment system of domestic wastewater and evaluation of soil transfer function (Paris Basin, France). Environmental Earth Sciences 73:7435-7444. https://doi.org/10.1007/s12665-014-3917-y

Oh S, Wang Q, Shin WS, Song D-I (2013) Effect of salting out on the desorption-resistance of polycyclic aromatic hydrocarbons (PAHs) in coastal sediment. Chemical Engineering Journal 225:84-92. https://doi.org/10.1016/j.cej.2013.03.069

Pot V, Benoit P, Menn ML, et al (2011) Metribuzin transport in undisturbed soil cores under controlled water potential conditions: experiments and modelling to evaluate the risk of leaching in a sandy loam soil profile. Pest Management Science 67:397-407. https://doi.org/10.1002/ps.2077

Pyzola S (2013) Nitrate Reduction Coupled to Iron (II) and Manganese (II) oxidation In An Agricultural Soil. University of Kentucky,

Reemtsma T, Mehrtens J (1997) Determination of polycyclic aromatic hydrocarbon (PAH) leaching from contaminated soil by a column test with on-line solid phase extraction. Chemosphere 35:2491-2501. https://doi.org/10.1016/S0045-6535(97)00317-2

Rennert T, Meißner S, Rinklebe J, Totsche KU (2010) Dissolved Inorganic Contaminants in a Floodplain Soil: Comparison of In Situ Soil Solutions and Laboratory Methods. Water Air Soil Pollut 209:489-500. https://doi.org/10.1007/s11270-009-0217-3

Rennert T, Rinklebe J (2010) Release of Ni and Zn from Contaminated Floodplain Soils Under Saturated Flow Conditions. Water Air Soil Pollut 205:93-105. https://doi.org/10.1007/s11270-009-0058-0

RFSC (2019) R: A language and environment for statistical computing. R Foundation for Statistical Computing

Roden EE, Wetzel RG (2002) Kinetics of microbial Fe (III) oxide reduction in freshwater wetland sediments. Limnology and Oceanography 47:198-211

Schlautman MA, Morgan JJ (1993) Effects of aqueous chemistry on the binding of polycyclic aromatic hydrocarbons by dissolved humic materials. Environ Sci Technol 27:961-969. https://doi.org/10.1021/es00042a020 
Schuwirth N, Hofmann T (2006) Comparability of and Alternatives to Leaching Tests for the Assessment of the Emission of Inorganic Soil Contamination (11 pp). J Soils Sediments 6:102-112. https://doi.org/10.1065/jss2005.10.149

Seidl M, Gromaire M-C, Saad M, De Gouvello B (2013) Effect of substrate depth and rain-event history on the pollutant abatement of green roofs. Environmental Pollution 183:195-203. https://doi.org/10.1016/j.envpol.2013.05.026

Seidl M, Huang V, Mouchel JM (1998) Toxicity of combined sewer overflows on river phytoplankton: the role of heavy metals. Environmental Pollution 101:107-116. https://doi.org/10.1016/S0269-7491(98)00008-6

Shaheen SM, Rinklebe J (2014) Geochemical fractions of chromium, copper, and zinc and their vertical distribution in floodplain soil profiles along the Central Elbe River, Germany. Geoderma 228-229:142-159. https://doi.org/10.1016/j.geoderma.2013.10.012

Souvestre Q (2013) Aménagement dans une zone de fortes contraintes

Suna Erses A, Onay TT (2003) In situ heavy metal attenuation in landfills under methanogenic conditions. Journal of Hazardous Materials 99:159-175. https://doi.org/10.1016/S03043894(02)00354-0

Thums CR, Farago ME, Thornton I (2008) Bioavailability of trace metals in brownfield soils in an urban area in the UK. Environ Geochem Health 30:549-563. https://doi.org/10.1007/s10653008-9185-6

Tian W, Wang L, Li D, Li F (2015) Leachability of phenanthrene from soil under acid rain and its relationship with dissolved organic matter. Environ Earth Sci 73:3675-3681. https://doi.org/10.1007/s12665-014-3653-3

US EPA (2017) Leaching Environmental Assessment Framework (LEAF) How-To Guide

US EPA O (2015) The SW-846 Compendium. In: US EPA. https://www.epa.gov/hw-sw846/sw846-compendium. Accessed 11 Nov 2020

Van der Sloot HA (1996) Developments in evaluating environmental impact from utilization of bulk inert wastes using laboratory leaching tests and field verification. Waste Management 16:6581

Walsh CJ, Roy AH, Feminella JW, et al (2005) The urban stream syndrome : current knowledge and the search for a cure

Wang W, Massey Simonich SL, Xue M, et al (2010) Concentrations, sources and spatial distribution of polycyclic aromatic hydrocarbons in soils from Beijing, Tianjin and surrounding areas, North China. Environ Pollut 158:1245-1251. https://doi.org/10.1016/j.envpol.2010.01.021

Zsolnay A, Baigar E, Jimenez M, et al (1999) Differentiating with fluorescence spectroscopy the sources of dissolved organic matter in soils subjected to drying. Chemosphere 38:45-50. https://doi.org/10.1016/S0045-6535(98)00166-0 